\title{
Alternatives to Synthetic Insecticides in the Control of the Colorado Potato Beetle (Leptinotarsa decemlineata Say) and Their Environmental Benefits
}

\author{
Bastian Göldel *(1), Darija Lemic (1) and Renata Bažok (1) \\ Department of Agricultural Zoology, Faculty of Agriculture, University of Zagreb, Svetošimunska 25, \\ 10000 Zagreb, Croatia; dlemic@agr.hr (D.L.); rbazok@agr.hr (R.B.) \\ * Correspondence: bastian.goeldel@web.de
}

Received: 3 November 2020; Accepted: 5 December 2020; Published: 8 December 2020

check for updates

\begin{abstract}
In this study, we review the wide range of alternative control methods used to this day to control the Colorado potato beetle (Leptinotarsa decemlineata Say), the biggest potato pest globally. We further categorize and highlight the advantages and disadvantages of each method by comparing them to conventional insecticides. In a second step, we point out the current knowledge about positive and negative impacts of using alternative control methods. By this, we illustrate how alternative control methods, farmers' activities, and environmental factors (e.g., biodiversity and ecosystem health) are heavily linked in a cycle with self-reinforcing effects. In detail, the higher the acceptance of farmers to use alternative control methods, the healthier the ecosystem including the pest's enemy biodiversity. The following decrease in pest abundance possibly increases the yield, profit, and acceptance of farmers to use less conventional and more alternative methods. Overall, we try to balance the positive and negative sides of alternative control methods and combine them with current knowledge about environmental effects. In our view, this is a fundamental task for the future, especially in times of high species loss and increasing demand for environmentally friendly agriculture and environmentally friendly products.
\end{abstract}

Keywords: biodiversity; biopesticides; conventional insecticides; crop farming; ecosystem health; environmental protection; insect ecology; natural enemies; pest control; sustainable agriculture

\section{Introduction}

Nowadays, we are witnessing the rapid introduction of organic farming all over the world and especially in Europe. Furthermore, the European Commission of the European Parliament aims to achieve a sustainable use of pesticides in the EU [1]. The intention of all member states is to reduce the risks and impacts of the excessive use of pesticides on human health and the environment and to promote the use of alternative approaches or techniques, such as non-chemical alternatives to pesticides and compliance with the principles of integrated pest management (IPM) [1]. The Biodiversity Strategy adopted in 2020, as well as the "Farm to Fork Strategy", includes the adoption of reduction targets for pesticides. Therefore, the wider implementation of alternative methods that can replace or reduce pesticide use is necessary for both organic and integrated farming methods.

The Colorado potato beetle (CPB), Leptinotarsa decemlineata Say (Coleoptera: Chrysomelidae), is native to North America with origin in central Mexico and was primarily known to only feed on few wild host plants [2,3]. In the US for a long time, its range was restricted to the eastern part of the Rocky Mountains, where it fed, for instance, on the buffalo bur, Solanum rostratum Dunal, a plant of no economic importance for farmers. As soon as the potato (Solanum tuberosum L.) was established 
in the area, the CPB adapted to feed on potato crops and began to spread towards the east, reaching the American East Coast by 1874 [2,4]. Larvae and adults mainly feed on the foliage of the host plants, with larvae being more damaging as they can cause high economic losses to farmers. Although the potato is the favorite food source of the $\mathrm{CPB}$, the beetles feed on various agricultural important plants such as cabbage (Brassica oleracea L.), pepper (Piper nigrum L.), tobacco (Nicotiana tabacum L.), eggplant (Solanum melongena L.), and tomatoes (Solanum lycopersicum L.) [5]. It also attacks a wide variety of weeds such as mullein (Verbascum Thapsus L.), thistle (Cirsium vulgare (Savi) Ten.), henbane (Hyoscyamus niger L.), belladonna (Atropa belladonna L.), and horse nettle (Solanum carolinense L.) [6]. The CPB is not only a threat to its native continent, but also for many areas worldwide [3]. For instance, the first European population of CPBs was discovered in Germany just a few years after spreading in the US, but was prevented from establishing as an invasive species. That kept the pest successfully out of Europe for the next 45 years. In 1922, it was rediscovered in France and since the end of the last century, the pest had spread over large parts of Europe and eastern and central Asia. As its reach continues to expand, the beetle potentially could spread also to temperate areas of Australia and New Zealand, Africa, Latin America, and India [7].

The adult beetles normally spend the winter hidden several inches deep in the soil or in woody vegetation close to or within potato fields. In spring, they walk or fly for up to several kilometers in search of potato or other host plant fields [8]. They establish themselves on a plant and start reproducing. Females lay egg masses on the undersides of leaves in batches of approximately 25 eggs. As the eggs are laid in clumps, the larvae tend to be found in clumps, as well [9]. Each female is able to lay as many as 600 eggs in total. The main damage on potato leaves is caused by larval feeding. If not controlled, CPBs may generate up to 100 percent defoliation months before the growing season ends, decreasing tuber yields by over 50 percent [10]. Annually, in cooler areas, the beetles complete one generation, in milder areas up to three generations [2,9]. All these life cycle characteristics and its behavior make the $\mathrm{CPB}$ a very successful and harmful pest for global potato production.

The potato has several characteristics that make it especially suitable for production in developing countries. Potatoes can be grown in areas of limited land, grow fast, are adaptable, are high yielding, and are responsive to low inputs. Together with rice, wheat, and maize, potatoes represent more than $50 \%$ of the world's food energy needs [11]. In 2012, in China, the economic loss caused by CPBs was estimated to be 3.2 million USD per year. The potential annual economic loss after the completion of its invasion is estimated to be 235 million USD [12]. Similar numbers were estimated for Russia, where a loss of more than $75 \%$ of potato plant foliage could lead to an annual complete crop loss if $\mathrm{CPB}$ is not controlled effectively [13].

Conventional insecticides (mainly synthetically produced chemicals) for many years have been used against $\mathrm{CPB}$, primarily due to their rapid action. Nevertheless, it resulted in numerous problems related to pest resistance to active substances contained in such chemical protection products. [14,15]. This has often prompted the development of even more chemical control tools, which is neither ecologically nor very economically friendly [16]. Furthermore, it triggered the elimination of the pests' natural enemies as well as the residues of toxic substances in food, water, air, and soil. It also caused the disturbance of an ecological balance and could also have an adverse impact on human health [14]. Additionally, the use of synthetic insecticides is not allowed in organic farming systems, because of the pressure of consumers for the use of environmentally friendly substances only [17]. Due to the unsustainable and unprofitable use of insecticides, compatible and ecologically friendly methods and products are needed to improve CPB pest management. These alarming aspects led to searching for new, alternative methods of domesticated plant pest controls, which would be safer for the natural environment and human well-being [18]. Hence, at the moment, organic agriculture plays a major role within the agricultural industry and research [19].

In our view, all CPB control methods could be divided into those that are used indirectly or preventively and target either the cultivation system or the potato plant itself. As direct methods, we consider various tools to prevent pest outbreaks by controlling (killing) the pest directly (Figure 1). 


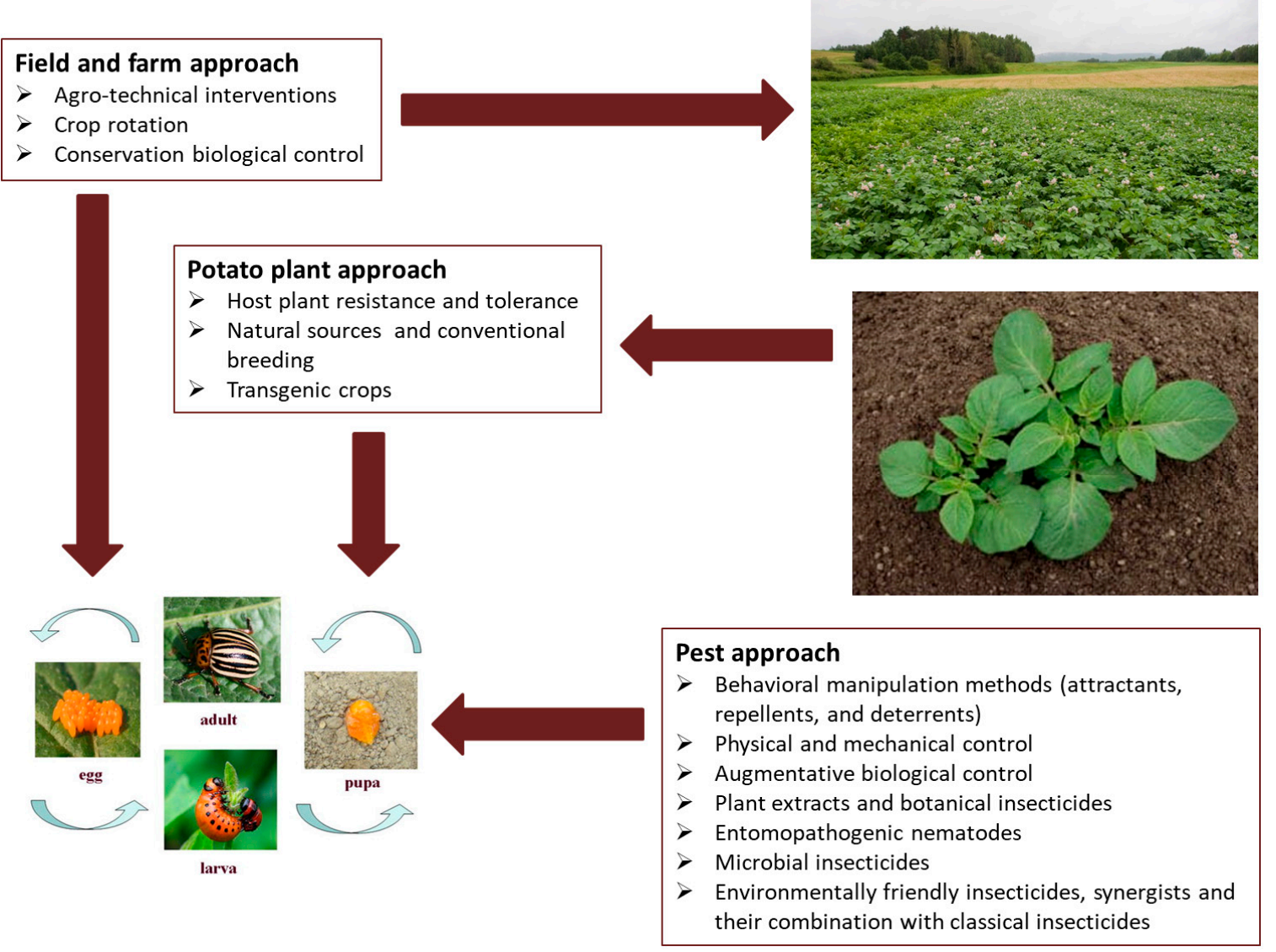

Figure 1. Schematic overview of different categories of available Colorado potato beetle control methods and their target sites.

As alternatives to chemical insecticides, all the methods that do not include the application of synthetic insecticides or include their application in reduced doses are considered. Here, we provide an overview of recent developments in alternatives, often ecologically more sustainable, methods of controlling $\mathrm{CPB}$, the world's largest pest in potato fields. Furthermore, to the best of our knowledge and belief, we are trying for the first time to link these tested alternative methods with conservation biological effects. In addition, the impacts are assessed not only by highlighting the positive (and negative) effects of alternative control methods on the environment (e.g., biodiversity and ecosystem health), but also vice versa. In our view, these methods could represent a fundamental approach in a world of environmental destruction and loss of biodiversity on one hand, but also contribute to a growing awareness of farmers and consumers of environmentally friendly agricultural products on the other.

\section{Alternative Control Methods}

\subsection{Indirect Methods for $C P B$ Control}

Indirect methods for $\mathrm{CPB}$ control include all agro-technical interventions during the potato growing season as are choice of the variety, crop rotation, soil tillage, fertilization, irrigation, other pest control measures, etc. Among all of them, crop rotation and selection of plant varieties are the most powerful in $\mathrm{CPB}$ control.

\subsubsection{Crop Rotation}

Crop rotation is the successive cultivation of different crops in a specified order on the same fields, which prevents the cultivation of the same crop system in two consecutive years on the same field or even area [20]. It is often able to slow down CPB population buildups, but it has to be ensured that 
fields are properly isolated to avoid easy infestations [20,21]. The impacts of crop rotation and distances between fields on pest populations were first investigated in research from the 1990s [22]. Scientists observed that the distances between rotated fields and the closest potato fields of the previous year were highly related to pest outbreaks on current fields. The further the potato field of the current season was away from the previous season's field, the fewer pest problems the farmers had $[9,21]$. However, not many studies suggest that crop rotation alone is a suitable method of controlling strong pests such as $\mathrm{CPB}$, but that it could be integrated into a management plan together with other alternative methods [20].

\subsubsection{Host Plant Resistance}

Host plant resistance and tolerance can either occur naturally through evolution and selection or artificially through human, transgenic input [9]. Some are believed to be more successful against $\mathrm{CPB}$ infestations than others. However, there is no potato variety which is considered to be fully CPB resistant [23], although several potato plant varieties have shown effects in laboratory studies on CPB development time and mortality (e.g., Agria, Pasinler, Marfona, Granola, Caspar) often due to mortality of eggs and immature CPB stages and decrease of fecundity and reproductive rate [24]. Sablon et al. [10] summarized several studies indicating that genetic manipulation, the direct manipulation of an organism's genes using biotechnological methods, of potato plants can be used to intensify the expression of deterrent blends. The incorporation of genes that express leptin and other glycoalkaloids in conventional and wild potato varieties resulted in improved tuber yields and a protecting effect against CPB in field and laboratory trials [25].

The transgenic approach describes the strategy for the genetic modification of the pest's host plant. As a result, the plant produces certain substances that are avoided when parts of the plant are consumed or that cause severe damage to the pest $[9,20,23]$. As transgenic potato varieties are not approved for organic cultivation, basically all varieties that are currently open to the agricultural market are unusable. Furthermore, genetically modified plants that are resistant to insect pests are often not considered a suitable approach in IPM, at least in the case of potato farming. As IPM is mandatory in agricultural production, transgenic plants are not allowed to be used in EU countries, although some of the events (mainly maize varieties) have been registered in some countries. In these countries, farmers can use the seeds from GM plants but they are not eligible to receive state subsidies. Irrespective of their success, the use of genetically modified crops often represents a suitable control method, but also contemporarily inadequate to a majority of consumers, especially in Europe [9].

RNA interference (RNAi) is one additional biotechnology to preserve crops from being infested by pests which has gained a lot of attention within recent years. RNAi might successfully trigger the silencing of certain target genes causing mortality or at least reducing pest fertility and health [26,27]. Using plant protease proregions as regulators, directly induced through bacteria Escherichia coli of cysteine proteinases, is another possible alternative. In certain biotechnological systems, the ability to preserve the integrity of companion defense-related proteins from the action of insensitive proteases in target pests has been demonstrated [28]. Many more transgenic approaches to pest control by bacteria, fungi, and other microbes are now available on the market and could be used as an alternative to control pests such as CPB, especially outside of Europe in North and South American countries [9,29].

Overall, host plant resistance was proven to be an effective control mechanism against CPB through various studies tested in the field. The potato varieties showing full $\mathrm{CPB}$ resistance are those created by the transgenic approach. Even though these methods are not accepted by farmers and consumers who favor pure organic or ecological farming [20] and are not allowed in IPM, the adoption of GM plants resistant to pests and diseases can reduce pesticide use and ensure potato production. There is an open debate on the value of genetically modified food, its potential to solve many of the worlds' hunger and malnutrition problems, and its impact on the environment by increasing yield and reducing reliance upon chemical pesticides [10,23]. 


\subsection{Direct Methods for CPB Control}

\subsubsection{Behavioral Interference Methods for CPB}

Chemical signals that regulate the behavior of insects usually consist of a mixture of odor substances emitted by plants, insects, and other animals. One type of signal is the aggregation pheromones [30]. For instance, the male-insect-produced unique pheromone (S)-3,7-dimethyl-2-oxo-oct-6-ene-1,3-diol was identified for $\mathrm{CPB}$, and both male and female were found to be attracted to the pheromone in laboratory bioassays [31]. The potential for the use of aggregation pheromone in CPB management was observed in the early 2000s in field trials where the pitfall traps baited with the aggregation pheromone were used to capture the colonizing CPB adults coming to the newly planted field. Even though over five times as many CPBs were captured in pheromone traps in comparison to controls, the efficacy decreased after only five days. Nevertheless, the potential for the use of the aggregation pheromone in CPB management was observed [32]. This method could only be effective at the beginning of the beetle emergence and colonization of newly planted potato fields, when mean daytime temperatures are below $20^{\circ} \mathrm{C}$ and adults are not able to fly.

In field experiments, synthetic blends of (R)-and (S)-enantiomers of the same pheromone were tested. Mixtures with as much as $87 \%$ or higher optical purity of the second enantiomer attracted CPBs most effectively [33]. The compound was also tested as a combination with various other potato volatiles (e.g., 2-phenylethanol and nonanal) in field and laboratory tests. A mixture with a three-component plant attractant was detected to be most successful. In another experiment, scientists treated potato plants with (Z)-3-hexenyl acetate (p/-)-linalool and methyl salicylate, a synthetic host volatile mixture, to test the attraction to few days old adult CPBs. For the plant treatment, they used four different doses and compared them to potato plants treated with azadirachtin-based antifeedant as well as untreated plants as control. All the experiments were conducted in greenhouses. The researchers figured out that the beetles favored plants nursed with the attractants over the ones with antifeedant, while only the highest antifeedant dose showed better results than the control. This shows the potential of synthetic attractants as components of a "stimulo-deterrent strategy", rather than antifeedants (at low doses) alone [34].

Behavioral responses of $\mathrm{CPB}$ were investigated through bioassays in the laboratory. The scientists tested a variety of 13 different compounds all emitted naturally from potato plants. In addition, they used compounds from tomatoes and soybeans [35]. Beetles were attracted by potato volatiles of damaged foliage, but not by tomato plants. Among the 16 odor components, six blends were attractive, two repellents, and eight without preferences. Even at low concentrations, (Z)-3-hexenyl acetate $(+/-)$-linalool and methyl salicylate were most attractive, while blends with rather high quantities of volatiles from leaves indicated opposite effects. In general, it was revealed that there are certain blends, even within the compound portfolio of potato (and tomato) host plants, that should be further investigated and considered for CPB management [35].

The efficacy of limestone dust as a deterrent at two different concentrations was tested as well. It was successful in decreasing the number of CPBs (eggs and larvae) during the individual stages of development, such as against eggs and from first to fourth instar larval stages [36].

Sablon et al. [10] also summarized several chemical compounds categorizing them into masking odors, trap crops including attractants and aggregation pheromones, and antifeedants [10]. In addition to some of the above-described extracts, they listed a multitude of antifeedants including hydroxides, alcohol extracts of the leaves and bark of Quercus alba L., limonin, $\alpha$-mangostin, sesquiterpenes, terpenoids, lactones, and extracts from various plants including wild species of potatoes. Most of these compounds led to a successful decrease in beetle feeding behavior, but also could potentially prevent female oviposition. This was detected for citrus limonoids, but also some other blends [10]. Therefore, behavioral interference methods can be an efficient and environmentally friendly way of CPB management. They represent a strongly increasing application in potato management through 
laboratory and field studies, while the most widely used methods such as chemical treatments decrease [10].

\subsubsection{Physical and Mechanical Control}

One approach that aroused bigger attention in the 1980s and 1990s was the bug vacuum [37]. With this method, insects were sucked from the plants into a large machine combined with a tractor pulling it and killed. However, the machine was never a great success as it came with too many agricultural and environmental disadvantages. It also killed useful and beneficial insects and other animals, but also caused heavy soil compaction due to its weight. The biggest problem was the low success against pests which were found deeper within the crop canopy that could not be reached, so a wide application of this method was never an option [37].

Assays in laboratories identified the usage of wood ash as a possible compound for CPB management due to its toxicity against adults and larval stages [38]. When exposing beetles permanently to wood ash for up to 10 days, all beetles of all stages were killed. The decreasing efficacy after repeated usage as well as the decreasing activity in the field within moist environments were the main detected problems. Nevertheless, the author of the study suggested that thick layers of ash applied as strips around the base of potato plants could act as a physical barrier like a fence, limiting big colonization of beetles as CPBs avoid crossing it [38].

Another alternative possibility to decrease CPB populations is physical control. Pneumatic and thermal pest controls can be used to control various stages within the development of the plant and beetle [39]. Here, scientists use the fact that in the early season, when potato plants start to grow out of the soil, plants are supposed to be less vulnerable to heat than adult beetles and eggs. Propane burners are directed towards the crop rows and eliminate most beetles while plants remain rather healthy [40]. Therefore, to control overwintering CPBs, the efficacy of flame technology was demonstrated for plant sizes of around eight inches in height [41]. The highest control efficacy was reached during sunny, warm days as CPBs are more active and often feed on the top of potato plants. Compared to most common insecticides which achieve a control rate of normally $25-50 \%$ of overwintering adults, flaming can be very efficient. In field tests, burning of beetles obtained up to a $90 \%$ fatality rate as well as a $30 \%$ reduction in the number of eggs to hatch [41]. Under laboratory and field conditions, a single-row insect scorcher for $\mathrm{CPB}$ control was tested accordingly. By controlling the temperature of the gasses and contact time in adult beetles, $60 \%$ of individuals were injured while the potato plants were not damaged [42].

Laboratory and field investigations illustrated that a combination of steam and air left more than $50 \%$ of adult CPBs incapacitated while barely damaged the potato plants. In detail, steam of low pressure was injected into a plant-covering hood $[39,43]$. It is also known that the CPB answers to disturbances by undergoing a defense strategy defined as thanatosis. By that, the beetles release hold from their host plants and just fall to the ground. Thanatosis can be initiated by using hot air and blowing it on CPBs feeding on the plant [40]. In some studies, researchers found out that the main causes of falling were related to certain exposure time, temperatures, and air velocity [39,40]. Afterward, the apparatus collected the air blown insects with its equipped collection device. Around $65 \%$ of fallen beetles could be collected this way [44]. For removed beetles that fall to the ground between crop rows, shielded propane burners were applied to kill them. Here, the effectiveness was at least as efficient as chemical insecticides [39,40].

Another way to hinder pest insects to enter crop fields is the usage of plastic-lined trenches and row covers which can function as physical barriers [45]. For that, synthetic fabric is used to avoid CPBs entering the potato fields. The material can be improved by fine soil particles and arranged in an angle wider than $46^{\circ}$ to make it impossible for most beetles to have a firm hold on the surface. Even though small numbers of beetles may be able to escape during rain showers when washed away, the material regains its protection as soon as it is dried afterward [45]. A portable variant was 
developed by Canadian scientists. With this version placed at field-edges, CPBs are able to walk up the sides of the trap, but from there get captured when falling into the inside [24].

The CPB is mainly diurnal, but can also be active at night. In one experiment, it was tested how strong the positive phototactic behavior of the beetle was in darkness, when stimulated with different wavelengths of light [46], respectively if low-intensity yellow light was favored over pheromones [47]. In both experiments, continuous yellow light (and in the first experiment also green light) was the most successful wavelength source to affect, capture, and control CPB individuals [46,47]. Physical and mechanical methods are promising alternatives to not only control pest populations efficiently, but also contribute to clean air and water by eliminating insecticide spraying completely.

\subsubsection{Augmentative Control}

The natural enemy complex for each pest, as well as for the $\mathrm{CPB}$, is geographically specific. The $\mathrm{CPB}$ is attacked by different generalist predators, but their presence depends on the geographic area and crop field type. They are subject to conservation biological control. Contrary to that, specific predators are not widely distributed and are used as augmentative control and parasitoids. The augmentative biological control uses insect predators [48] as well as parasitoids. The CPB has several natural enemies, but they can be hardly found in most potato fields, especially with heavy usage of conventional insecticides [20]. Within alternative and organic farming systems, the abundance and richness of natural enemies are higher, but are unlikely to fully control the $\mathrm{CPB}$, even though some generalist predators provide good control [20,49].

The objective of several studies to diminish CPB populations focuses on insects of the order Hemiptera, including the Nearctic stink bug Perillus bioculatus (F.) $[4,50]$. The use of this predator to control the CPB has been successful in laboratory and microplot consumption tests. This bug is obviously not naturally abundant in all areas with $\mathrm{CPB}$ occurrences, especially not outside of its natural territories in North America [49]. P. bioculatus is a natural enemy of CPB in and could potentially also help to diminish CPB populations outside of North America [51]. To solve this problem, predators would have to be released in very high numbers using, for instance, mechanical distributors [49]. However, the production of huge amounts of predators could be difficult as for the suitable control of eggs and early larval stages of $\mathrm{CPB}$, certain temperatures and storage times of the predator nymphs are necessary to be an efficient pest control [50]. The main problem of newly introduced species is their unknown effect on the ecosystem and, therefore, they often not represent a safe and suitable option.

Finally, it was suggested and shown that the combination of sub-lethal effects of P. bioculatus with products based on Bacillus thuringiensis Berliner var. tenebrionis (Btt) could significantly increase CPB larval mortality in field experiments [52].

The spined soldier bug Podisus maculiventris Say is another Hemiptera species that can diminish populations of CPB. In 1997, O'Neill demonstrated in laboratory and field experiments predation behaviors of this predator towards the CPB. Due to higher prey-predator ratios in laboratories than in the wild, the experiments revealed a strong decrease in beetle populations [53]. Moreover, just as $P$. bioculatus, under natural conditions none of the investigated predators obtain large enough populations, or are even completely absent when the CPB starts into the new feeding season. This way, CPB outbreaks cannot be avoided [3]. Due to this and the fact that the distribution of P. maculiventris is relatively scarce in North America, one plausible strategy could be to collect and transfer the bugs from pheromone traps to nursery traps in the potato fields from where they start the suppression of $\mathrm{CPB}$ populations [4]. Hough-Goldstein and McPherson (1996) tested both P. bioculatus and P. maculiventris in experiments [49]. Although the latter showed less strong significant prey rates comparatively, older life stages were concentrated on larger $\mathrm{CPB}$ larval stages. So, the overall success rate between the two $\mathrm{CPB}$ predators could even be related to the predator's life stage and used accordingly.

In addition to Hemiptera, several other natural enemies of the Coleoptera order had been investigated to be successful CPB pest controls. Already in field experiments of the late 80s, Hazzard et al. illustrated significant effects of control in both early and late generations of the CPB using 
the 12-spotted ladybeetle Coleomegilla maculate Lengi in western Massachusetts [54]. For the same species during a bigger field experiment, Mallampalli et al. detected the impact of $C$. maculata on a composition of possible prey species [55]. They figured out through computer models that when (beside CPB) eggs of the European corn borer (Ostrinia nubilalis Hübner, Lepidoptera) were found in the area, predation on beetle eggs highly became positively density dependent. When larvae and adults of the green peach aphid Myzus persicae Sulzer (Homoptera) were present, similar results were obtained accompanying a significant decrease of $\mathrm{CPB}$ individuals. These results witnessed that present control, as well as resistance management strategies, should also consider the composition of prey species when developing management strategies, but more research is needed especially through field experiments [55].

The carabid beetle Lebia grandis Say is one of many natural enemies native to North America. The larvae of these beetles are obligate parasitoids, while also the adults feed on CPB eggs and larvae [16]. This predator represents one of the most important natural control species of CPBs in North America. As the activity of this predator peaks at night and it rarely appearance in pitfall trap studies, an insufficient amount of research about this species was conducted so far $[16,50]$. Other field studies from Idaho indicated that the introduced generalist ground beetle $P$. melanarius might be a useful biocontrol within CPB pest management. Large numbers of eggs and larvae were consumed by adult predators. Hence, the pest population decreased more in untreated than in insecticide-treated fields, because a higher abundance of predator individuals fed on pest individuals [56].

Larval stages of the lacewing (Chrysoperla carnea (Stephens)), a Neuroptera species, might represent another good alternative to control CPB populations. Even if field assays are still needed, laboratory studies highlighted a valuable ability to control beetle larvae, with greatest efficacy on the youngest stages [57].

Within the Hymenoptera order, the parasitic wasp Edovum puttleri Grissell seems to be an effective weapon against $C P B$ damage in potato fields. First, a computer model was built to calculate the possible parasitism of CPB eggs. This algorithm incorporated the specific attack behavior of E. puttleri, and the development time for parasitized egg masses [58].

The use of natural enemies may be another option to control CPB populations, but many of those are not abundant in nature and manual release in large areas is not very practical [59]. One promising solution could be the mechanical (physical) distribution of predators. In a test study, huge amounts of predators were mixed in containers with a carrier material. In the field, the containers were opened mechanically at various spots and all predators released at once [60]. Obtained results indicated that the mechanical release of predators ended in a better control of beetle populations and egg masses than manual release $[2,60]$.

Augmentative control could be a valuable approach due to its low negative impact on ecosystem health and biodiversity. We focused on some of the most investigated arthropod parasites and parasitoids in research studies. Species of mites, phalangids, spiders, and parasitic flies (Tachinidae) were discovered to be able to control CPB populations [49]. Still, it has to be mentioned that many (described) experiments were conducted in the laboratory and only have a theoretical value if not also tested in the fields and large geographical scales.

\subsubsection{Use of the Plant Extracts and Botanical Insecticides}

Since 1990, biopesticides are slowly but steadily replacing synthetic, conventional pesticides and are even used commercially [61-64]. They are often (besides hydrolytic compounds or primary metabolites) generated from compounds that are produced by plants in secondary metabolites, often after pest infestation or in harsh environmental situations [65]. They appear as repellents or antifeedants and help to resist against a broad range of pest species by increasing their mortality or decreasing the reproduction ability [66]. Although biopesticides seem to be a promising way to replace conventional, chemical insecticides, they are still underexplored and the practical application is still limited [67]. 
Plant extracts and botanical insecticides represent two different types of products: homemade products as well as commercially available botanical insecticides. Even if they originate from nature, their properties are not always acceptable for plant protection $[10,23]$. However, commercially available botanical insecticides have been subject to the same registration procedure as chemical pesticides. If they are approved, they are, therefore, considered safe for use with all restrictions as stated on the label. A comprehensive review of 48 different plant extracts and botanical insecticides tested against the $\mathrm{CPB}$ (including only a few widely used commercial products) shows that some of the plant extracts have a high potential for $\mathrm{CPB}$ control and should be investigated further [10].

A small number of commercial and widely used botanical products are on the market for use against CPB. Rotenone is a biopesticide that is one root extract from several species within the Fabaceae family [68]. Since it kills pests rather slowly, it can be associated with pyrethrum for a more rapid effect, lasting for up to two days [69]. It should be used carefully as it is also poisonous to non-target insects as well as to domestic and farm animal species. The European Union (EU) began a phase-out of rotenone in 2008 [70]. The final authorization was withdrawn on 31 October 2011. Therefore, rotenone is not approved for use in the EU or any EU member state [71].

The effects of Origanum vulgare L. extracts have been discussed in several papers [14,72]. Experiments demonstrated that extracts gained from the dry and fresh matter at the highest concentrations contributed to the greatest reduction of females and males feeding on potato plants. Similar results were observed after the application of lower concentrations, but only in females [14]. Moreover, the morbidity of the essential oil of Iranian lemongrass, Cymbopogon citrates Stapf, was positively assessed against adults and third instar larvae of CPBs. The higher the concentration, the stronger the effect against the pest [73].

In additional studies conducted in Turkey, potato leaves were prepared with three different extract solutions of five different plant species (Arctium lappa L., Bifora radians (M.Bieb), Humulus lupulus L., Xanthium strumarium L., Verbascum songaricum Schrenk) and then exposed to the larvae of CPB. Observations of larval behavior during one day of exposure revealed that the plant blends significantly influenced the interaction between beetles and leaf tissue. This was not the case for very low concentrations-only the medium (except $V$. songaricum) and high extract (all species) concentrations [74]. In another similar experiment, extracts of Acanthus dioscoridis L., Achillea millefolium L., Bifora radians, Heracleum platytaenium Boiss, H. lupulus, and Phlomoides tuberosa L. were tested against different larval stages for two days. For second to fourth instar larval stages, H. lupulus and H. platytenium reached the highest CPB mortality rate while the first larval stage was more susceptible [75].

Different essential oils of Eugenia caryophyllus (Sprengel), Mentha spicata L., Myrtus communis L., Ocimum basilicum L., Satureja khuzistanica Jamzad, and Thymus daenensis Celak were tested for their nutritional indices and mortal efficacy against adults and fourth instar larvae of CPB. All essential oils showed a deterrent effect, with the most efficient oil coming from S. khuzistanica [18]. Several authors examined the effects of ethanolic extracts obtained from various parts of Liquidambar orientalis L., Buxus sempervirens L., Alnus glutinosa (L.) Gaertn., Artemisia absinthium L., Aesculus hippocastanum L., and Rhus coriaria L. on the egg-laying behavior of CPBs in the laboratory. Afterward, the antifeedant and toxic effects of the two most effective extracts leading to the smallest number of egg-laying, L. orientalis and B. sempervirens, were tested in a field study. Both extracts indicated significant decreases in egg numbers of CPBs and seemed to be potentially successful in the field as an alternative to chemical pesticides [76].

In the laboratory, first-generation $\mathrm{CPB}$ adults were treated with Artemisia vulgaris L. and Satureja hortensis L. The extracts of both plants had no lethal effect on adult mortality. Nevertheless, in both cases, the aqueous extract solutions induced a higher percentage of sterility of eggs compared to the alcoholic extract, while the effect on eggs treated with Artemisia variants was higher than that with Satureja [77]. Furthermore, the effects of compounds from two Piperaceae species, Piper nigrum L. and Piper tuberculatum Jacq., against adults and larval CPBs were assessed with several different plant extract concentrations [78]. It was found that early larval stages of few days were most vulnerable 
in both plant species. Additionally, the activity of P. nigrum indicated that contact toxicity was most effective when early instar larvae were targeted. Late instar larvae could be knocked down with higher concentrations and 50\% of the adults could be killed with a high application. P. nigrum lost much of its repellent function under pure sunlight. Nevertheless, pepper species could be suitable biopesticides since they are among the most traded species, they are relatively safe to use and store, and seed and leaf material are universally available [78,79].

In an experiment with many different plant species, the contact and residual toxicity of 30 plant extracts was investigated on third instar CPB larvae. The insects were sprayed and the effectiveness was measured every $24 \mathrm{~h}$ for one week. After a 24-h incubation, blends of Artemisia vulgaris L., Hedera helix L., H. lupulus, Lolium temulentum L., Rubia tinctoria L., Salvia officinalis L., Sambucus nigra L., Urtica dioica L., $V$. songaricum, and X. strumarium killed significantly more beetles than the control. In general, a longer incubation time than $24 \mathrm{~h}$ did not show higher values. The H. lupulus extract was the most toxic of all products, causing $99 \%$ beetle mortality [4]. Fresh and dry matter of wild thyme (Thymus serpyllum L.) in different concentrations was tested on the feeding behavior of CPB adults and larvae. For efficient control of adults, a dry matter extract with the highest tested concentration $(10 \%)$ should be used, while larvae at the fourth instar appeared to be significantly more vulnerable [80].

Stilbenes are phenolic compounds that are produced in several vines in large quantities and function as plant defenses. Oligomeric forms were proven to be very efficient against a broad range of pests. The aim of a study conducted by Gabaston et al. was to explore the activity of a grapevine root extract containing a stilbene oligomer pool [81]. In the laboratory, the extracts showed toxic effects on larvae and slowed down their development and food intake, while in field experiments, high CPB mortality could be observed. In addition, the extract also killed non-targeted organisms, such as earthworms (Eisenia fetida Savigny). The authors emphasized that grapevine roots still represent promising sources of bioactive compounds to create alternative insecticides [81].

In the study by Trdan et al., refined rapeseed oil (Brassica napus L.) and slaked lime were tested under laboratory conditions for their efficacy against CPB larvae and adults at three different temperatures [82]. Heat or cold did not play a specific role as the tested substances caused significant damage to beetles at each temperature. Adults were the most sensitive developmental stage and revealed the highest mortality rate, while refined oil was discovered to be the stronger beetle repellent [82].

Various products of azadirachtin, which is produced from neem tree seeds, showed effects against the CPB. In one study, neem (along with several other bio-insecticides) was suggested as an effective control agent against CPB larvae and adults [82]. On the plants treated with azadirachtin, between $8 \%$ and $32 \%$ of eggs were left unhatched. This effect was reported even 7-8 days after the end of hatching on the untreated control [83]. However, neem concentrations of more than $1 \%$ can potentially lead to phytotoxicity in potato plants. Although once considered benign to beneficial insects and effective against the $\mathrm{CPB}$, neem products have also demonstrated some adverse effects as it was found to be poisonous to ladybirds, particularly in early larval stages [84]. Neem has also been found less effective than Btt [85].

A two seasons field experiment in Canada evaluated the use of spraying plant blends as an alternative control of the CPB. The herbs evaluated as companions to potato plants were bush beans, flax (Linum usitatissimum L.), French marigold (Tagetes patula L.), horseradish (Armoracia rusticana Gaertn., C.A.Mey. \& Scherb.), and tansy (Tanacetum vulgare L.). A capsaicin extract, a garlic extract, a neem seed extract, a Btt product, and a pine extract were tested as controls [19]. This showed that plant individuals sprayed with neem extract experienced higher yields, lower beetle density, and less defoliation than each of the other treatments and the control. Btt controlled all, but mainly larval stages (less the adults) of CPBs, but in total less than neem. On the other hand, garlic and capsaicin extracts, as well as companion planting, did not diminish CPB densities in potatoes. This raised concerns about the use of companion plants without first testing their efficacy, but also demonstrated the potential success of this approach [19]. 
The best known and oldest botanical insecticide is a powder obtained by grinding the dried flowers of the Dalmatian pyrethrum plant, Chrysanthemum cinerariaefolium Trev. and related species C. coccineum Wild. It is a wide spectrum insecticide effective against many different pests. Laboratory and field investigations demonstrated that the efficacy of pyrethrin was between $83 \%$ and $86 \%$ in the laboratory and between $86 \%$ and $88.0 \%$ in field trials [86]. In the same trials, the efficacy of neem extract was between $62 \%$ and $63 \%$ in laboratory trials and between $55 \%$ and $88 \%$ in field trials. The efficacy of both insecticides was significantly lower than the efficacy of the standard insecticide spinosad and at the same level as the efficacy of $B t t$ [86]. The main field advantage is that it dissolves quickly in direct sunlight without spreading widely in the crop plants [15].

Finally, pyola is a natural compound that contains canola oil and pyrethrins. It is applied not only against the $\mathrm{CPB}$, but also against several other insect pests. Since a large part of rapeseed oil available commercially used comes from genetically modified plants, this product may not be in line with rules of organic farming despite its success in pest management [23].

\subsubsection{Entomopathogenic Nematodes}

Several species of entomopathogenic nematodes were proven to be very effective against the CPB $[87,88]$. For a laboratory experiment, the effects of native isolates of entomopathogenic nematodes, Heterorhabditis bacteriophora Poinar, Steinernema carpocapsae Weiser, and Steinerma feltiae Filipjev, against late larval stages of $\mathrm{CPBs}$ were evaluated at different temperatures. All nematode species achieved higher mortality rates than the control, including elevated success rates under increasing temperatures [89]. In an additional laboratory experiment by Toba et al., fourth instar CPBs were placed in cups containing soil treated with a Mexican strain of S. feltiae, and in another with S. glaseri Steiner [88]. They found that both nematode species were equally effective against CPB larvae, although different soil and nematode densities could influence the effect. The most common damaging effects against $\mathrm{CPB}$ larvae were wing deformation and detained development, which both can affect CPB fitness of adult individuals [90]. Furthermore, Trdan et al. also detected a higher mortality rate of $\mathrm{CPB}$ larvae and adults with rising nematode concentrations and temperatures during laboratory bioassays for H. bacteriophora, H. megidis Poinar, S. carpocapsae, and S. feltiae [91].

Introduced nematode species from areas elsewhere could be sometimes a more effective alternative solution for some areas than naturally occurring nematodes. Their introduction could be necessary as $\mathrm{CPB}$ populations may be able to develop tolerances to naturally occurring species as the CPB is also increasingly able to develop tolerances against commercial insecticides [92]. In laboratory experiments, exotic Heterorhabditis species, H. marelatus Lui \& Berry, H. bacteriophora, and H. indica Poinar, Karunakar \& David, were more pathogenic for the CPB than the endemic Heterorhabditis strains from Oregon, while the other exotic Steinernema oregonense Liu \& Berry and S. riobrave Cabanillas, Poinar \& Raulston species were in the middle of both in terms of efficacy [92]. Nevertheless, most experiments were only conducted in laboratories. The successful use in the field still has to be proven and would depend on cheap mass production of nematodes as host infection would have to be most likely applied through spraying machines.

\subsubsection{Microbial Insecticides}

Microbial insecticides are based on microorganisms that cause different pathological reactions (sometimes death) of target insects. They may be based on viruses, protozoa, bacteria, and fungi. There are many microbial biopesticides on the market. Here, we focus on bacteria and fungi as they are used to produce two of the probably most widespread and popular biopesticides, also for the usage against the $\mathrm{CPB}$. One evolved from the bacterium Bacillus thuringiensis var. tenebrionis (Btt), which has become increasingly accessible within the last years. Btt is basically only effective if it is ingested. Sprayed, it is most successful against newly hatched CPB larvae, so it should be used in the fields around this time [2,93]. Another bio-compound is derived from the entomopathogenic fungus Beauveria bassiana (Bals.-Criv.) Vuill. (1912). Unlike Btt, B. bassiana represents an efficient 
control against adults and all larval stages of the CPB and it is able to continue propagating after the application. This presents a very high degree of control during the entire potato growing season. Most notable limitations of $B$. bassiana seem to be its vulnerability to high temperatures and drought. Therefore, B. bassiana might not be of high importance for growers in warm, dry regions [94]. Other options could be specific bacteria such as Bacillus popillae Dutky 1941 and Bacillus lentimorbus Dutky 1940 which have been positively tested against several pests in laboratory experiments, as well as certain species of protozoa [95]. However, to our knowledge, most of these species have not yet been efficiently tested against the CPB in field trials.

\subsubsection{Environmentally Friendly Insecticides, Synergists and Their Combinations with Classical Insecticides}

Synthetic pesticides are not allowed in organic farming. The use of insecticides in IPM is only permitted if the pest population reaches an economic threshold. Among the registered insecticides, there are some that are less dangerous for the environment and humans than others. We consider these insecticides as environmentally friendly ones. The group of insecticides that are more suitable for CPB control (i.e., environmentally friendly) in the IPM program is represented by four active ingredients of different origins: $B t t$, neem extract, natural pyrethrin, and spinosad. All of them are also approved for organic farming approaches [23,32]. Compared to classical insecticides, their use reduces environmental pollution and the impact on beneficial entomofauna. The addition of sub-lethal doses of chemical insecticides to biological insecticides to improve their efficacy was investigated by Kovacevic (1960) and later discussed by Benz (1971) [96]. Barčić et al. [96] found that combinations of environmentally friendly insecticides with classical insecticides can lead to different benefits at lower doses: (i) ecological, because the use of lower doses decrease pollution, and (ii) biological, because the use of combinations might slow down the development of resistance. In addition, the combined action of the insecticides used could lead to a synergistic effect (iii) economically, because the cost per treatment is lower.

Commercial formulations of spinosad applied at three different concentrations $(0.2 \%, 0.1 \%$, and $0.05 \%)$ and temperatures $\left(15,20\right.$, and $25{ }^{\circ} \mathrm{C}$ ) were tested against the $\mathrm{CPB}$ in the laboratory. Spinosad intoxicated beetles both by contact and ingestion. Experiments revealed that a temperature of $15{ }^{\circ} \mathrm{C}$ with a concentration of $0.2 \%$ in combination caused significantly higher mortality of adult insects than other temperatures and concentrations [17]. Similar positive effects were experienced in other laboratory and field experiments for spinosad and combinations with other ecological insecticides [96-98]. In addition to spinosad, the mixture of avermectin B1 (80\%) and avermectin B1b (29\%), and avermectin C also reached strong efficacy against third instar larvae and adults [96]. Concerning combinations with spinosad, mixtures with $B t t$, azadirachtinand pyrethrin proved to be very active in both laboratory and field studies (Barčić et al., 2006). Furthermore, the efficacy of low doses of spinosad, $B t t$, and azadirachtin has been detected and the effect of combinations for these three alternative insecticides has been proposed [97].

In addition, the efficacy of neem and karanja oil in binary mixtures against CPB larvae was investigated [99]. The experiment demonstrated a synergistic effect in laboratory trials. The most effective blend with ratio 1:1 was similar or more effective than neem oil alone and increased with exposure time. It was also demonstrated that doses can be lowered but still achieve an improved mortality effect against larval stages of the CPB [99]. Moreover, neem is a potential insect growth regulator, especially in combination with Btt [100].

Further research evaluated the relevance of synergistic effects between capsaicin and organophosphate insecticides against the CPB [20]. The addition of capsaicin to the compound at various temperatures led to an increase in insect mortality by almost one quarter at higher, and three quarters at lower temperatures, compared to organophosphate alone. [101]. There are also several other combinations of environmentally friendly and conventional insecticides that are being tested constantly; some are more and some are less effective against the $\mathrm{CPB}$. 


\subsubsection{Conservation Biological Control}

Conservation biological control is the implementation of practices that maintain and enhance the efficacy of natural enemies. As it was mentioned earlier, there are just a few specific natural enemies that attack the $\mathrm{CPB}$, but often are only spread at a limited geographic range. Therefore, the complex of generalist predators that attack different developmental stages of the CPB is location-specific and not well investigated $[10,102]$. Not many papers are dealing with the complex of natural enemies for potato plants, but generally, authors agree that CPB populations are commonly preyed upon by a variety of generalist arthropod predators, including predatory bugs of the genera Orius and Geocoris, as well as in general Carabidae, Cantharidae, and Opiliones [102-104].

Plant diversity in the vicinity of or on potato fields, e.g., through margins, improves the habitats for natural enemies of the CPB near, outside, or directly inside the fields [7]. Refuge strips often contain both grasses and herbs that provide shelter and resources for predatory arthropods, and flowering plants which are inviting to generalist predators and parasitoids feeding on organic material. This can have a positive effect on crop growth $[105,106]$. Stripes can also help to minimize the use of synthetic chemicals in potato farming as they reduce the likelihood that action thresholds are reached. Encouraging the increases in enemy abundances and diversity can strengthen pest management and help to conserve and improve agroecosystems [107]. Increasing the habitat of natural enemies by providing food sources such as leaves, pollen, and nectar within the field or along field boundaries can, therefore, improve the overall efficacy of conservation biological controls [105].

Focusing directly on the $\mathrm{CPB}$, research showed that increased biodiversity can provide better ecosystem services for effective pest control, as alternative methods can lead to increased species richness, evenness, and even larger potato plants [108]. This knowledge is supported by findings that also predators are more abundant in communities with high evenness as they have to compete less with others than with individuals of their species. That is direct proof that a higher diversity of natural enemies leads to improved ecosystem services and functional diversity [108,109]. It was also proposed that companion planting, also labeled "agronomic pendant of plant biodiversity", diminishes the successive colonization of the CPB into potato fields, particularly on organic farms due to increased botanical background noise. That makes host-finding for the pest more difficult [20]. In a study by Johnson and colleagues, they found no significant differences in the number of CPB adults, but more larval individuals in control than in straw plots-possibly again due to different predation rates of natural enemies [110].

Finally, mulch generates microenvironments that benefit CPB predators. In the first half of the season, soil predators-mainly ground beetles—climb on potato plants to feed on second and third instar larvae of CPBs. In the second half of the season, ladybirds and lacewings are the main predators, feeding on eggs and younger larval stages of CPBs. On mulch, there were more predators than on non-mulched plots, following in significantly less damage of potato plants by the beetles [20]. Interestingly, it can often be an advantageous solution to use a healthy ecosystem with improved living conditions for a species-rich environment (including natural enemies of the pest) instead of conventional insecticides to protect crop yields from high pest populations.

In general, there are still many open questions and knowledge is very vague. In most cases, it is not known how single alternative approaches influence specific ecology factors, such as biodiversity, ecosystem services, functional diversity, or pollination success. This shows that a lot more research is needed here to disentangle specific methods and their exact impacts, negative and positive. All conservation biological methods (beside all other alternative ones) are listed in Table 1. 
Table 1. Alternative methods with examples: the table shows the different categories of alternative control methods to control the Colorado potato beetle (CPB). Within each category, the individual methods are listed in more detail, including the studies and papers in which these methods were presented. The number in brackets indicates the corresponding study in the reference list.

\begin{tabular}{|c|c|c|}
\hline Alternative Method & Treatment Example [and Literature Reference Number] & Comments on Treatment Details nd/or Future Prospects \\
\hline Crop rotation & Rotation and field distance $[10,20,22]$ & effective when large field distances \\
\hline \multirow{3}{*}{ Host plant resistance } & RNA interference $[26,27]$ & applied increasingly, powerful tool, but not for organic farming \\
\hline & Resistant potato varieties $[28,29]$ & various results, no $100 \%$ protection \\
\hline & Transgenic $[10,20,23]$ & often used successfully, but not for organic farming \\
\hline \multirow{11}{*}{ Behavioral interference methods } & 3,7-dimethyl-2-oxo-oct-6-ene-1,3-diol [31,32] & good potential, also in field studies \\
\hline & (Z)-3-hexenyl acetate (b/-)-linalool [33,34] & good potential, also in field studies \\
\hline & $\alpha$-mangostin [10] & efficient, also against $\mathrm{CPB}$ oviposition \\
\hline & Lactones [10] & efficient, against oviposition and larvae \\
\hline & Limestone dust [34] & strong, especially against larval stages \\
\hline & Limonin [10] & efficient, also against $\mathrm{CPB}$ oviposition \\
\hline & Methyl salicylate $[34,35]$ & good potential, also in field studies \\
\hline & Quercus alba L. [10] & efficient, also against $\mathrm{CPB}$ oviposition \\
\hline & Pheromone combinations [30] & very efficient, especially in the field \\
\hline & Sesquiterpenes [10] & reduces $\mathrm{CPB}$ feeding and oviposition \\
\hline & Terpenoids [10] & efficient, against oviposition and larvae \\
\hline \multirow{6}{*}{ Physical and mechanical control } & Fire and burner [40-42] & higher mortality than most insecticides \\
\hline & Nets and trenches [45] & good but not very high efficiency in field \\
\hline & Mechanical predator distributor $[3,49]$ & efficient, but depends on predator species \\
\hline & Pneumatic $[37,39,43,44]$ & very efficient, but complicated in field \\
\hline & Traps $[46,47]$ & very high efficiency in field tests \\
\hline & Wood ash [38] & highly efficient, but reduced with moisture \\
\hline \multirow{8}{*}{ Augmentative control } & Chrysoperla carnea (Stephens) [58] & efficient vs. early larvae, field studies needed \\
\hline & Coleomegilla maculate Lengi $[54,55]$ & efficient in many field studies since 1980s \\
\hline & Edovum puttleri Grissell [58] & successful control, more field studies needed \\
\hline & Lebia grandis Say $[16,50]$ & strong in laboratory, more field studies needed \\
\hline & Perillus bioculatus (F.) $[4,48-51]$ & efficient control in laboratory and field studies \\
\hline & P. bioculatus + Bacillus thuringienses Berliner (Bt) [52] & very successful \\
\hline & Podisus maculiventris Say $[4,49,53]$ & successful, not lower in field than laboratory \\
\hline & Pterostichus melanarius (Illiger) [56] & very efficient vs. eggs and larvae \\
\hline
\end{tabular}


Table 1. Cont.

\begin{tabular}{|c|c|c|}
\hline Alternative Method & Treatment Example [and Literature Reference Number] & Comments on Treatment Details nd/or Future Prospects \\
\hline \multirow{31}{*}{ Plant extracts and botanical insecticide } & Acanthus dioscoridis L. [74,75] & protects potato leaves $1-2$ days in field \\
\hline & Achillea millefolium L. $[74,75]$ & protects potato leaves $1-2$ days in field \\
\hline & Aesculus hippocastanum L. [76] & successful in field studies \\
\hline & Alnus glutinosa L. [76] & successful in field studies \\
\hline & Arctium lappa L. [74] & efficient, especially mid-high doses \\
\hline & Armoracia rusticana L. [19] & weak effects in field trials \\
\hline & Artemisia absinthium L. [77] & successful in field studies \\
\hline & Artemisia vulgaris L. $[5,77]$ & efficient, also against $\mathrm{CPB}$ eggs \\
\hline & Bifora radians (M.Bieb) $[74,75]$ & efficient, especially mid-high doses \\
\hline & Brassica napus L. [82] & efficient in laboratory, strong vs. adults \\
\hline & Buxus sempervirens L. [76] & very successful in field studies \\
\hline & Capsaicin extract [19] & more efficient in synergistic use \\
\hline & Cymbopogon citrates Stapf [73] & successful in laboratory vs. larvae \\
\hline & Eugenia caryophyllus (Sprengel) [18] & efficient vs. larvae, adults in laboratory \\
\hline & Garlic extract [20] & weak effects in field trials \\
\hline & Grapevine root extract [80] & toxic especially for larval development \\
\hline & Hedera helix L. [5] & successful in laboratory studies \\
\hline & Heracleum platytaenium Boiss [73] & strong, especially against larval stages \\
\hline & Humulus lupulus L. [5,72,73] & causes very high $\mathrm{CPB}$ mortality \\
\hline & Linum usitatissimum L. [19] & weak effects in field trials \\
\hline & Liquidambar orientalis L. [76] & very successful in field studies \\
\hline & Lolium temulentum L. [5] & successful in laboratory studies \\
\hline & Mentha spicata L. [18] & efficient vs. larvae, adults in laboratory \\
\hline & Myrtus communis L. [18] & efficient vs. larvae, adults in laboratory \\
\hline & Neem seed extract [19] & successful in laboratory and field studies \\
\hline & Ocimum basilicum L. [20] & efficient vs. larvae, adults in laboratory \\
\hline & Origanum vulgare L. $[14,72]$ & strong, also in low doses still vs. females \\
\hline & Phlomoides tuberosa L. [75] & efficient in laboratory tests \\
\hline & Pine extract [19] & weak effects in field trials \\
\hline & Piper nigrum L. [78] & efficient, loses function under sunlight \\
\hline & Piper tuberculatum L. [78] & efficient, especially vs. early larval stages \\
\hline
\end{tabular}


Table 1. Cont

\begin{tabular}{|c|c|c|}
\hline \multirow[t]{18}{*}{ Alternative Method } & Treatment Example [and Literature Reference Number] & Comments on Treatment Details nd/or Future Prospects \\
\hline & Pyola [23] & successful, not for organic farming if contains GM oilseed rape oil \\
\hline & Pyrethrin [86] & high efficacy in laboratory and field \\
\hline & Rhus coriaria L. [76] & efficient also in field studies \\
\hline & Rotenone $[23,69]$ & efficient, but very toxic, also to mammals, not allowed in EU \\
\hline & Rubia tinctoria L. [5] & efficient in laboratory studies \\
\hline & Salvia officinalis L. [5] & successful in laboratory studies \\
\hline & Sambucus nigra L. [5] & successful in laboratory studies \\
\hline & Satureja hortensis L. [77] & effects on eggs, not СРB adults \\
\hline & Satureja khuzistanica Jamzad [18] & very efficient against larval stages \\
\hline & Slaked lime [84] & efficient against adults in laboratory studies \\
\hline & Tagetes patula L. [19] & successful in laboratory and field studies \\
\hline & Tanacetum vulgare L. [19] & successful in laboratory and field studies \\
\hline & Thymus daenensis Celak [18] & efficient vs. larvae, adults in laboratory \\
\hline & Thymus serpyllum L. [80] & strong vs. larvae in mid-high concentrations \\
\hline & Urtica dioica L. [5] & successful in laboratory studies \\
\hline & Verbascum songaricum Schrenk $[5,74]$ & only vs. larvae with high concentrations \\
\hline & Xanthium strumarium L. $[5,74]$ & efficient, especially vs. early larval stages \\
\hline \multirow{9}{*}{ Entomopathogenic nematodes } & Heterorhabditis bacteriophora Poinar $[87,89,91]$ & good efficiency with high temperatures \\
\hline & Heterorhabditis indica Poinar [92] & very efficient in laboratory experiments \\
\hline & Heterorhabditis marelatus Lui \& Berry [92] & efficient in laboratory experiments \\
\hline & Heterorhabditis megidis Poinar [91] & good efficiency with high temperatures \\
\hline & Steinernema carpocapsae Weiser $[89,91]$ & good efficiency with high temperatures \\
\hline & Steinernema feltiae Filipjev [88-91] & good efficiency with high temperatures \\
\hline & Steinernema glaseri Steiner [88] & successful vs. larvae in laboratory studies \\
\hline & Steinernema oregonense Lui \& Berry [92] & medium successful in laboratory tests \\
\hline & Steinernema riobrave Cabanillas [92] & medium successful in laboratory tests \\
\hline \multirow{2}{*}{ Microbial insecticides } & Bacillus thuringienses Berliner $(B t)[2,93,94]$ & very successful \\
\hline & Beauveria bassiana (Bals.-Criv.) Vuill. (1912) $[94,95]$ & very successful \\
\hline
\end{tabular}


Table 1. Cont.

\begin{tabular}{|c|c|c|}
\hline Alternative Method & Treatment Example [and Literature Reference Number] & Comments on Treatment Details nd/or Future Prospects \\
\hline \multirow{7}{*}{$\begin{array}{l}\text { Environmentally friendly insecticides, synergists and } \\
\text { their combinations with synthetic insecticides }\end{array}$} & Azadirachtin $[82,84]$ & lethal, but improvement needed \\
\hline & Capsaicin + Organophosphate [101] & widely used, successful combination \\
\hline & Avermectin C [96] & especially successful vs. CPB adults \\
\hline & Karanja oil + Azadirachtin [99] & promising, field studies needed \\
\hline & Avermectin B1 + B1b [96] & strong, but less than actara, spinosad \\
\hline & Azadirachtin $+B t[100]$ & successful, but not for organic farming \\
\hline & Spinosad and combinations $[17,96-98]$ & very successful synergistic effects \\
\hline \multirow{2}{*}{ Conservation biological control } & Mulching (wheat or rye straw) [111] & weak, better combined with other methods \\
\hline & Natural enemy diversity $[52,106-109,112,113]$ & very efficient, but complex system \\
\hline
\end{tabular}




\section{Effects of Alternative Control Methods on the Environment}

The relationship between alternative pest control methods and biodiversity is not a one-sided relationship. Some studies have indicated that the utilization of commercial, synthetic compounds for CPB management seems to have direct toxic impacts on vulnerable target individuals, but also indirect effects on non-target species from various phyla, such as soil-dwelling arthropods [110]. This can disrupt entire food webs leading to communities that are dominated by very few resistant species, while most others disappear from the system [109]. The dynamics of foliar biodiversity are to be negatively affected by insecticide treatments on various crops $[104,114,115]$. Observations in experiments found that the abundance of foliar arthropods was at its lowest level in years when plantations were sprayed with different insecticides five times a year. On the other hand, insect abundance was much higher in years with only two foliar sprays [106]. In another study, the biomass, the number of earthworms, and the abundance and richness of soil collembolas and mites had decreased significantly after one season of conventional potato cultivation. After that, it usually takes about 3-4 years until the biodiversity reaches the same level as it used to before the use of conventional insecticides $[48,112]$.

The use of the above-described alternatives to synthetic insecticides can decrease the broad spectrum of negative environmental effects on the ecosystem's health that the use of synthetic insecticides causes. Often this corresponds to high species richness, composition, evenness, and ecosystem services [116]. Through many studies, it is highly recognized that organic farming promotes healthier and more diverse ecosystems than conventional farming [117]. This was confirmed by results of several studies that were conducted on small plots, entire fields, or even big farms [108]. In organic fields, a high proportion of flowering plants in the upper canopy might be able to improve the feeding conditions for many arthropods. The presence of a variety of visible flowers and visiting insects can make organic fields much more attractive to people who seek relaxation in agricultural areas [117]. Organic farming also increases the functional diversity, including important functional groups of plants, pollinators, and predators that can improve natural pest control $[106,118,119]$. For example, research on birds, small mammals, insects, invertebrates, and various soil organisms almost exclusively showed higher levels and diversity on organic farmland compared to conventional farms, including a higher proportion of rare or threatened species [116,119].

MacFadyen et al. found that organic farms contain higher species richness at three trophic levels: plant, herbivore, and parasitoid [120]. In a later study, they concluded that insect network modules on conventional farms have fewer connections among themselves than on organic ones, which could decrease the stability of these networks. Geiger found higher soil-seed density and weed biomass on organic farms, while seed density positively correlated with both bird species richness and abundance [121]. High community evenness, which is much more present on organic than conventional farms, was found to be positively correlated to stable interactions between soil microbes and plants [122]. Moreover, farming practices that deploy alternative methods of CPB control can result in higher soil organic matter, increased microbial activity, less erosion due to thicker topsoil, cleaner ground and surface water quality, less nitrogen pollution, fewer greenhouse gas emissions, and reduced energy consumption (e.g., fossil energy and pesticides) [123,124]. At the local level, field-margin habitats favored a more diverse carabid beetle fauna than pure potato fields. On a larger scale, beetle diversity on potato fields rose while community composition changed with the increase of natural area that was present within a $1.5 \mathrm{~km}$ radius around the field [113]. In another experiment, the number of coccinellids found was significantly higher in fields inter-planted with dill and coriander than in control fields without additional flowering plants. The survival rate of CPB larvae was much lower in dill fields than in the control. Strip-intercropping with properly flowering species is able to significantly improve the conservation of $\mathrm{CPB}$ predators and increase biodiversity and reproduction in vegetable production systems [125].

Perhaps the most important aspect of avoiding conventional, synthetic insecticide applications is the fact that it can even have long-term negative impacts on ecologically friendly pest control $[106,118]$. 
Conventional broad-spectrum synthetic insecticides can disrupt the communities of natural enemies of pests-resulting in less efficient control results. For example, the former use of carbofuran to control the European corn borer and the $\mathrm{CPB}$ has suppressed or even eliminated predator communities, including ground beetles, in eastern North Carolina with negative effects on CPB control and potato plants [116]. Crowder et al. carried out a study of biological pest control in agricultural systems and investigated whether organic farming promotes pest control by increasing the biodiversity of the natural enemy community in potato fields in Washington [108]. They found a higher species evenness in organic fields where natural enemies were relatively evenly distributed, compared to conventional fields dominated by one enemy species that accounted for up to $80 \%$ of individuals. In line with this discovery is that a higher evenness of natural enemies particularly decreased CPB abundance through direct attacks either against adults by various insect predators or against the larvae by entomopathogenic nematodes in the soil. Alyokhin and Atlihan, and Alyokhin et al. partially supported the findings on potato plants by demonstrating that $\mathrm{CPB}$ populations on manure-amended plots were not only lower but also took longer to develop than on chemically fertilized ones $[8,126]$. Natural enemy populations increased in further research with rising overall insect diversity and suppressed the pest population [127]. Due to mulching, carabids were found to be more abundant and diverse compared to un-mulched fields, especially in potato fields. Mulching increased the total amount of captured beetles with $17 \%$ more on hay mulched and $14 \%$ on leaf litter mulched plots [111]. Higher abundances of natural enemies on mulched than on non-mulched plots were very likely responsible for an expansion in yield due to a reduction of CPB leaf feeding [128,129]. Therefore, an increase in overall biodiversity in a healthy ecosystem is often accompanied by an increase in the number of natural enemies of the pest. Ideally, this can lead to a self-reinforcing effect, i.e., a subsequent decrease in pest numbers increases the yield and profit of farmers, improves acceptance of natural control methods, and slowly eliminates synthetic insecticides [108].

In conventional potato farming, the main interest is to evaluate under which circumstances a high benefit (yield) could be achieved most efficiently including minimum negative effects on the farm business [48]. For several years already, synthetic chemical insecticides have continued to be marked as bad or even evil in public opinion; thus, they have a bad reputation. The ability of insect pests to develop resistances against many insecticides as one major aspect forces continual renewal of the existing insecticide inventory which noticeably reduces the overall absolute benefit of conventional production $[48,106]$. Turnbull and Hector illustrated that escalating resistance can lead to increased insecticide spraying including an increasing, ever-wider variety of chemicals, and spiraling costs for farmers [109]. It was further suggested that alternative and ecologically friendly methods which increased natural enemy diversity and evenness of CPBs lead to an increase in potato yield through fewer pests and larger plants as well as the option for farmers to use less cost-intensive insecticides $[108,130]$. In a review about several crop types planted under various conventional and alternative control conditions, it was detected slightly, often not significant, lower yields in sustainable production. The authors explain the low advantage of conventional methods by the fact that the best conditions for sustainable farming often lack suitable know-how for best application procedures, showing high potential for improvement. In addition, most data from conventional farming was found in developed areas with high-input farming and, thus, over-average yields [131]. Sustainable and ecologically based agriculture can improve the quality of the environmental and natural resource bases upon which the agriculture depends. This can also maintain the (economic) sustainability of farms, and considerably improve the well-being of farmers and the whole society [48]. The higher the acceptance by farmers to use more alternative and ecologically friendly methods, the healthier the ecosystem, as well as the biodiversity of the pest enemies, could be expected. This can potentially reduce pest abundance, further increase yields and profits, and increase farmers' acceptance of using fewer conventional and more alternative control methods (Figure 2). 


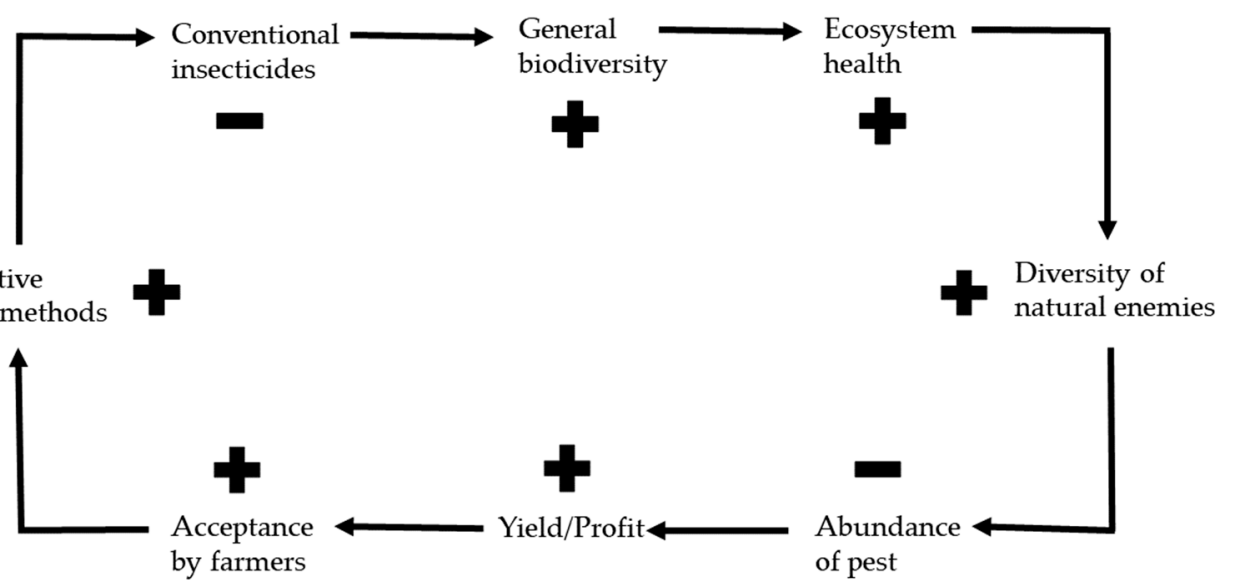

Figure 2. Self-reinforcing effects between alternative control methods and biodiversity: + indicates the increase, - the decrease of its corresponding expression next to it. The increased usage of alternative methods leads to less usage of conventional insecticides, which improves the general biodiversity and ecosystem health. The following higher diversity of natural enemies decreases the pest abundance which leads to a higher yield and profit for the farmer. By that, the acceptance for alternative methods improves including the increase of its usage instead of conventional ones.

In addition, pure alternative control methods and the development of new, ecologically friendly compounds, integrated pest management (IPM) could be an alternative to pure conventional techniques. Here, conventional pesticides are being substituted by biological or behavioral control methods. One of the main goals of IPM is to limit the number of pesticides used by decreasing the amount or concentrations. Even if it requires effort to fully understand the synergistic effects between various mechanisms, it has been demonstrated that it can benefit farmers and the environment [132]. For instance, laboratory results indicated that entomopathogenic nematodes tended to reproduce better in CPBs fed on potato plants with high levels of bio-fertilizer [9]. Other results indicated that it is possible to lower the doses of neem and karanja oils and even receive improved efficacy against CPB larval vitality when combining [99], and, under field conditions, the biopesticides spinosad and avermectin caused almost as high mortalities as the conventional insecticide tiamethoxan and higher ones than pirimiphos-methyl [97].

Nevertheless, alternative methods are not free from criticism, for various reasons. First, producers and consumers are still reluctant to accept the approach, because of its complexity and unpredictability [133]. Decision-makers may find it hard to overcome the obstacles of implementation that could result from a lack of tools and know-how to handle the unpredictability of ecologically friendly control methods [48]. This naturally reduces the general acceptance of environmentally friendly methods. Preventing insect outbreaks by manipulating biotic interactions can also be tricky, because it additionally elevates the complexity and difficulty of insect protection systems [133]. Moreover, the micro-climate, local soil properties, and management history of a site heavily impact biota interactions and make it difficult to create proper pest control solutions appropriate for large geographical areas and available for every farmer $[48,134]$. As most invasive pests have intentionally or unintentionally been introduced through humans and often lack natural predators in their new environment, biological control can be challenging or almost impossible [48]. Additionally, a high predator density in organic fields does not necessarily result in low numbers of pests always and everywhere, as has also been shown in tests with the CPB [106]. If alternative methods act differently than expected, it is, therefore, possible that they may cause even more damage than the existing conventional pesticides they are supposed to eliminate [133]. Some techniques are at present time more promising than others, which might also have to do with the complexity of certain alternative methods as well as their under-investigation so far. 
Overall, the focus on pure profit is slowly decreasing while the focus on health and the environment is growing for various reasons and due to public opinion [48]. High costs for new conventional insecticides, pest resistance, and loss of biodiversity in a world of constant species loss under the threat of global warming are just some of the reasons to gradually shifting the focus to alternative pest control methods, such as for CPBs. Further research is needed to improve farming and pest control conditions, so that farmers and nature benefit equally by switching from conventional to alternative pest control methods worldwide.

\section{Conclusions}

We reviewed a wide range of alternative methods used to control the CPB. We listed, categorized, and highlighted the advantages and disadvantages of the methods, including in comparison to conventional insecticides. Next, we presented the current knowledge about the positive and negative effects of using alternative control methods and IPM of various control approaches. We also illustrated how alternative control methods, farmers, and environmental factors (e.g., biodiversity and ecosystem health) are strongly linked in a self-reinforcing cycle. The higher the acceptance of farmers for the use of alternative control methods, the healthier the ecosystem including pest's enemy biodiversity. The following decrease of pest abundance may increase the yield, profit, and acceptance of farmers to use less conventional and more alternative methods. There are still few studies that compare the actual yield and profit between fields controlled by using synthetic insecticides and some of the alternatives described here under the same environmental and anthropogenic conditions. The existing studies suggest that implementing IPM methods and using alternatives to synthetic insecticides can produce nearly as high or even higher yields than conventional farming, especially regarding the high potential of improving sustainable methods over time and experience. Overall, we are trying to balance the positive and negative sides of alternative control methods and combine them with current knowledge about environmental impacts. In our view, this is a fundamental task for the future, especially in times of high global species loss and increasing demand for environmentally friendly agriculture and products. Many alternative methods that already exist are often at least as good or even more efficient than their conventional counterparts. Moreover, the effectiveness and reputation of the latter ones are constantly declining, so the only logical conclusion is to improve alternative control methods. Those are still far from being perfect alternatives, so more research is needed, also to improve the efficacy, yield, profit, and understandability of methods for farmers. Some methods are already widely accepted and in use, such as certain IPMs with ecologically friendly insecticides or physical or augmentative control, while the pure utilization of conservation biological methods did not convince many farmers yet, although all of these methods show potential. Much more research is needed as alternative methods and their success is much less investigated and much more complex than most conventional ones. Still, it is broadly acknowledged that alternative control methods contribute greatly to a healthier environment from which everybody can profit. This leads us to believe that alternative control methods already play an appropriate role in agriculture and hopefully, in the long-term, can completely replace or at least diminish as much as possible pest control methods based on conventional and often environmentally harmful synthetic insecticides.

Author Contributions: The authors contributed as followed to the specific parts of the work: Idea of the topic, B.G. and R.B.; Investigation (literature research), B.G.; Conceptualization, B.G. and R.B.; Validation, B.G., D.L. and R.B.; Writing, B.G., Review and editing, B.G., D.L., and R.B.; Visualization, B.G. and R.B.; Supervision, R.B. All authors have read and agreed to the published version of the manuscript.

Funding: This research was supported by the Croatian Science Foundation through the project MONPERES (2016-06-7458) "Monitoring of Insect Pest Resistance: Novel Approach for Detection, and Effective Resistance Management Strategies".

Conflicts of Interest: The authors declare no conflict of interest. The funders had no role in the design of the study; in the collection, analyses, or interpretation of data; in the writing of the manuscript; or in the decision to publish the results. 


\section{References}

1. European Commission. Sustainable Use of Pesticides. 2020. Available online: https://ec.europa.eu/food/ plant/pesticides/sustainable_use_pesticides_en (accessed on 25 November 2020).

2. Cingel, A.; Savić, J.; Lazarević, J.; Ćosić, T.; Raspor, M.; Smigocki, A.; Ninković, S. Extraordinary adaptive plasticity of colorado potato beetle: "Ten-Striped Spearman" in the era of biotechnological warfare. Int. J. Mol. Sci. 2016, 17, 1538. [CrossRef] [PubMed]

3. Almady, S.; Khelifi, M.; Beaudoin, M.P. Control of the Colorado Potato Beetle, Leptinotarsa decemlineata (Say), Using Predator Insects Released by a Mechanical Prototype. J. Environ. Eng. Sci. 2012, 1, 1279-1287.

4. Aldrich, J.R.; Cantelo, W.W. Suppression of Colorado potato beetle infestation by pheromone-mediated augmentation of the predatory spined soldier bug, Podisus maculiventris (Say) (Heteroptera: Pentatomidae). Agric. Forest Entomol. 1999, 1, 209-217. [CrossRef]

5. Gökçe, A.; Whalon, M.E.; Çam, H.I.T.; Yanar, Y.; Demirtaş, İ.I.M.; Gőren, N. Contact and residual toxicities of 30 plant extracts to Colorado potato beetle larvae. Arch. Phytopathol. Pflanzenschutz 2007, 40, 441-450. [CrossRef]

6. Luckmann, W.H.; Metcalf, R.L. The Pest Management Concept. Introduction to Insect Pest Management, 1st ed.; Wiley: New York, NY, USA, 1994; pp. 1-31.

7. Alyokhin, A. Colorado potato beetle management on potatoes: Current challenges and future prospects. Fruit Veg. Cereal Sci. Biotechnol. 2009, 3, 10-19.

8. Alyokhin, A.; Atlihan, R. Reduced fitness of the Colorado potato beetle (Coleoptera: Chrysomelidae) on potato plants grown in manure-amended soil. Environ. Entomol. 2005, 34, 963-968. [CrossRef]

9. Armer, C.A.; Berry, R.E.; Reed, G.L.; Jepsen, S.J. Colorado potato beetle control by application of the entomopathogenic nematode Heterorhabditis marelata and potato plant alkaloid manipulation. Entomol. Exp. Appl. 2004, 111, 47-58. [CrossRef]

10. Sablon, L.; Dickens, J.C.; Haubruge, É.; Verheggen, F.J. Chemical ecology of the Colorado potato beetle, Leptinotarsa decemlineata (Say) (Coleoptera: Chrysomelidae), and potential for alternative control methods. Insects 2013, 4, 31-54. [CrossRef]

11. Wijesinha-Bettoni, R.; Mouillé, B. The Contribution of Potatoes to Global Food Security, Nutrition and Healthy Diets. Am. Potato J. 2019, 96, 139-149. [CrossRef]

12. Liu, N.; Li, Y.; Zhang, R. Invasion of Colorado potato beetle, Leptinotarsa decemlineata, in China: Dispersal, occurrence, and economic impact. Entomol. Exp. Appl. 2012, 143, 207-217. [CrossRef]

13. Maharijaya, A.; Vosman, B. Managing the Colorado potato beetle; the need for resistance breeding. Euphytica 2015, 204, 487-501. [CrossRef]

14. Rusin, M.; Gospodarek, J. The effect of water extracts from Origanum vulgare L. on feeding of Leptinotarsa decemlineata Say. J. Agric. Eng. 2018, 63, 122-127.

15. Liu, S.Q.; Scott, I.M.; Pelletier, Y.; Kramp, K.; Durst, T.; Sims, S.R.; Arnason, J.T. Dillapiol: A pyrethrum synergist for control of the Colorado potato beetle. J. Econ. Entomol. 2014, 107, 797-805. [CrossRef] [PubMed]

16. Weber, D.C.; Rowley, D.L.; Greenstone, M.H.; Athanas, M.M. Prey preference and host suitability of the predatory and parasitoid carabid beetle, Lebia grandis, for several species of Leptinotarsa beetles. J. Insect Sci. 2006, 6, 14-27. [CrossRef]

17. Kowalska, J. Spinosad effectively controls Colorado potato beetle, Leptinotarsa decemlineata (Coleoptera: Chrysomelidae) in organic potato. Acta Agric. Scand. B 2010, 60, 283-286. [CrossRef]

18. Saroukolai, A.T.; Nouri-Ganbalani, G.; Hadian, J.; Rafiee-Dastjerdi, H. Antifeedant activity and toxicity of some plant essential oils to Colorado potato beetle, Leptinotarsa decemlineata Say (Coleoptera: Chrysomelidae). Plant Protect. Sci. 2014, 50, 207-216. [CrossRef]

19. Moreau, T.L.; Warman, P.R.; Hoyle, J. An evaluation of companion planting and botanical extracts as alternative pest controls for the Colorado potato beetle. Biol. Agric. Hortic. 2006, 23, 351-370. [CrossRef]

20. Giordanengo, P.; Vincent, C.; Alyokhin, A. Insect Pests of Potato. Global Perspectives on Biology and Management, 1st ed.; Elsevier Inc.: Waltham, MA, USA, 2013.

21. Huseth, A.S.; Frost, K.E.; Knuteson, D.L.; Wyman, J.A.; Groves, R.L. Effects of landscape composition and rotation distance on Leptinotarsa decemlineata (Coleoptera: Chrysomelidae) abundance in cultivated potato. Environ. Entomol. 2012, 41, 1553-1564. [CrossRef] [PubMed] 
22. Weisz, R.; Smilowitz, Z.; Christ, B. Distance, rotation, and border crops affect Colorado potato beetle (Coleoptera: Chrysomelidae) colonization and population density and early blight (Alternaria solani) severity in rotated potato fields. J. Econ. Entomol. 1994, 87, 723-729. [CrossRef]

23. Kuepper, G. Colorado Potato Beetle: Organic Control Options; NCAT Program Specialist Tiffany Nitschke. HTML Production CT, 107, Slot 114; ATTRA: Fayetteville, NC, USA, 2003.

24. Yasar, B.; Güngör, M.A. Determination of life table and biology of Colorado potato beetle, Leptinotarsa decemlineata Say (Coleoptera: Chrysomelidae), feeding on five different potato varieties in Turkey. Appl. Entomol. Zool. 2005, 40, 589-596. [CrossRef]

25. Sinden, S.L.; Sanford, L.L.; Cantelo, W.W.; Deahl, K.L. Bioassays of segregating plants. J. Chem. Ecol. 1988, 14, 1941-1950. [CrossRef] [PubMed]

26. Cappelle, K.; de Oliveira, C.F.R.; Van Eynde, B.; Christiaens, O.; Smagghe, G. The involvement of clathrin-mediated endocytosis and two Sid-1-like transmembrane proteins in double-stranded RNA uptake in the Colorado potato beetle midgut. Insect Mol. Biol. 2016, 25, 315-323. [CrossRef] [PubMed]

27. Zhu, F.; Xu, J.; Palli, R.; Ferguson, J.; Palli, S.R. Ingested RNA interference for managing the populations of the Colorado potato beetle, Leptinotarsa decemlineata. Pest Manag. Sci. 2011, 67, 175-182. [CrossRef]

28. Visal, S.; Taylor, M.A.; Michaud, D. The proregion of papaya proteinase IV inhibits Colorado potato beetle digestive cysteine proteinases. FEBS Lett. 1998, 434, 401-405. [CrossRef]

29. Panevska, A.; Hodnik, V.; Skočaj, M.; Novak, M.; Modic, Š.; Pavlic, I.; Podržaj, S.; Zarić, M.; Resnik, N.; Maček, P.; et al. Pore-forming protein complexes from Pleurotus mushrooms kill western corn rootworm and Colorado potato beetle through targeting membrane ceramide phosphoethanolamine. Sci. Rep. 2019, 9, 1-14. [CrossRef]

30. Dickens, J.C. Plant volatiles moderate response to aggregation pheromone in Colorado potato beetle. J. Appl. Entomol. 2006, 130, 26-31. [CrossRef]

31. Dickens, J.C.; Oliver, J.E.; Hollister, B.; Davis, J.C.; Klun, J.A. Breaking a paradigm: Male-produced aggregation pheromone for the Colorado potato beetle. J. Exp. Biol. 2002, 205, 1925-1933.

32. Kuhar, T.P.; Mori, K.; Dickens, J.C. Potential of a synthetic aggregation pheromone for integrated pest management of Colorado potato beetle. Agric. Forest Entomol. 2006, 8, 77-81. [CrossRef]

33. Kuhar, T.P.; Hitchner, E.M.; Youngman, R.R.; Mori, K.; Dickens, J.C. Field response of Colorado potato beetle to enantiomeric blends of CPB I aggregation pheromone. Int. J. Agric. Sci. 2012, 3, 896-899. [CrossRef]

34. Martel, J.W.; Alford, A.R.; Dickens, J.C. Laboratory and greenhouse evaluation of a synthetic host volatile attractant for Colorado potato beetle, Leptinotarsa decemlineata (Say). Agric. Forest Entomol. 2005, 7, 71-78. [CrossRef]

35. Dickens, J.C. Orientation of Colorado potato beetle to natural and synthetic blends of volatiles emitted by potato plants. Agric. Forest Entomol. 2000, 2, 167-172. [CrossRef]

36. Gontariu, I.; Enea, I.-C. Protection against the proliferation of the Colorado beetle (Leptinotarsa decemlineata Say) in the concept of organic culture at the potato. Food Environ. Saf. J. 2017, 11, 91-96.

37. Moore, J. Sweeping fields controls some pests. Am. Veg. Grow. 1990, 1, 10-11.

38. Boiteau, G.; Singh, R.P.; McCarthy, P.C.; MacKinley, P.D. Wood ash potential for Colorado potato beetle control. Am. Potato J. 2012, 89, 129-135. [CrossRef]

39. Laguë, C.; Khelifi, M.; Gill, J.; Lacasse, B. Pneumatic and thermal control of Colorado potato beetle. Can. Agric. Eng. 1999, 41, 53-58.

40. Laguë, C.; Khelif, M.; Lacasse, B. Evaluation of a four-row prototype machine for pneumatic control of Colorado potato beetle. Can. Agric. Eng. 1999, 41, 47-52.

41. Moyer, D.D.; Derksen, R.C.; McLeod, M.J. Development of a propane flamer for Colorado potato beetle control. Am. Potato J. 1992, 69, 599-600.

42. Hicks, J.; Couturier, M.; Pelletier, Y. Insect scorcher for the control of the Colorado potato beetle. Can. Agric. Eng. 1999, 41, 227-232.

43. Pelletier, Y.; Misener, G.C.; McMillan, L.P. Steam as an alternative control method for the management of Colorado potato beetles. Can. Agric. Eng. 1998, 40, 17-22.

44. Couturier, M.; Hicks, J.B.; Rouison, D.; Pelletier, Y. Thermal initiation of thanatosis to improve the pneumatic removal of the Colorado potato beetle. Can. Biosyst. Eng. 2005, 47, 2.5-2.12. 
45. Boiteau, G.; Pelletier, Y.; Misener, G.C.; Bernard, G. Development and evaluation of a plastic trench barrier for protection of potato from walking adult Colorado potato beetles (Coleoptera: Chrysomelidae). J. Econ. Entomol. 1994, 87, 1325-1331. [CrossRef]

46. Otálora-Luna, F.; Dickens, J.C. Spectral preference and temporal modulation of photic orientation by Colorado potato beetle on a servosphere. Entomol. Exp. Appl. 2011, 138, 93-103. [CrossRef]

47. Otálora-Luna, F.; Dickens, J.C. Multimodal stimulation of Colorado potato beetle reveals modulation of pheromone response by yellow light. PLoS ONE 2011, 6, e20990. [CrossRef]

48. De Ladurantaye, Y.; Khelifi, M.; Cloutier, C.; Coudron, T.A. Short-term storage conditions for transport and farm delivery of the stink bug Perillus bioculatus for the biological control of the Colorado potato beetle. Can. Biosyst. Eng. 2010, 52,1-4.

49. Hough-Goldstein, J.; McPherson, D. Comparison of Perillus bioculatus and Podisus maculiventris (Hemiptera: Pentatomidae) as potential control agents of the Colorado potato beetle (Coleoptera: Chrysomelidae). J. Econ. Entomol. 1996, 89, 1116-1123. [CrossRef]

50. Greenstone, M.H.; Szendrei, Z.; Payton, M.E.; Rowley, D.L.; Coudron, T.C.; Weber, D.C. Choosing natural enemies for conservation biological control: Use of the prey detectability half-life to rank key predators of Colorado potato beetle. Entomol. Exp. Appl. 2010, 136, 97-107. [CrossRef]

51. Tarla, S.; Tarla, G. Detection of Perillus bioculatus (F.) (Heteroplera: Pentatomidae) on a New Host in Anatolia. Can. Entomol. 2018, 127, 195-212.

52. Cloutier, C.; Jean, C. Synergism between natural enemies and biopesticides: A test case using the stinkbug Perillus bioculatus (Hemiptera: Pentatomidae) and Bacillus thuringiensis tenebrionis against Colorado potato beetle (Coleoptera: Chrysomelidae). J. Econ. Entomol. 1998, 91, 1096-1108. [CrossRef]

53. O'Neil, R. Functional response search strategy of Podisus maculiventris (Heteroptera: Pentatomidae) attacking Colorado potato beetle (Coleoptera: Chrysomelidae). Environ. Entomol. 1997, 26, 1183-1190. [CrossRef]

54. Hazzard, R.V.; Ferro, D.N.; Van Driesche, R.G.; Tuttle, A.F. Mortality of eggs of Colorado potato beetle (Coleoptera: Chrysomelidae) from predation by Coleomegilla maculata (Coleoptera: Coccinellidae). Environ. Entomol. 1991, 20, 841-848. [CrossRef]

55. Mallampalli, N.; Gould, F.; Barbosa, P. Predation of Colorado potato beetle eggs by a polyphagous ladybeetle in the presence of alternate prey: Potential impact on resistance evolution. Entomol. Exp. Appl. 2005, 114, 47-54. [CrossRef]

56. Alvarez, J.M.; Srinivasan, R.; Cervantes, F.A. Occurrence of the carabid beetle, Pterostichus melanarius (Illiger), in potato ecosystems of Idaho and its predatory potential on the Colorado potato beetle and aphids. Am. Potato J. 2013, 90, 83-92. [CrossRef]

57. Sablon, L.; Haubruge, E.; Verheggen, F.J. Consumption of immature stages of Colorado potato beetle by Chrysoperla carnea (Neuroptera: Chrysopidae) larvae in the laboratory. Am. Potato J. 2013, 90, 51-57. [CrossRef]

58. Groden, E.; Drummond, F.A.; Casagrande, R.A.; Lashomb, J.H. Estimating parasitism of Colorado potato beetle eggs, Leptinotarsa decemlineata (Coleoptera: Chrysomelidae), by Edovum puttleri (Hymenoptera: Eulophidae). Great Lakes Entomol. 1989, 22, 47-54.

59. Boiteau, G. Insect pest control on potato: Harmonization of alternative and conventional control methods. Am. Potato J. 2010, 87, 412-419. [CrossRef]

60. De Ladurantaye, Y.; Khelifi, M. Design of a mechanical release system of Perillus bioculatus to control the Colorado potato beetle, Leptinotarsa decemlineata (Say). In Proceedings of the 17th World Congress of the International Commission of Agricultural and Biosystems Engineering (CIGR), Québec City, QC, Canada, 13-17 June 2010.

61. Chiasson, H.; Vincent, C.; Bostanian, N.J. Insecticidal properties of a Chenopodium-based botanical. J. Econ. Entomol. 2004, 97, 1378-1383. [CrossRef]

62. Thacker, J.R. An Introduction to Arthropod Pest Control, 1st ed.; Cambridge University Press: Cambridge, MA, USA, 2002.

63. Pascual-Villalobos, M.J.; Robledo, A. Anti-insect activity of plant extracts from the wild flora in southeastern Spain. Biochem. Syst. Ecol. 1999, 27, 1-10. [CrossRef]

64. Nitao, J.K. Test for toxicity of coniine to a polyphagous herbivore, Heliothis zea (Lepidoptera: Noctuidae). Environ. Entomol. 1987, 16, 656-659. [CrossRef] 
65. Bourgaud, F.; Gravot, A.; Milesi, S.; Gontier, E. Production of plant secondary metabolites: A historical perspective. Plant Sci. J. 2001, 161, 839-851. [CrossRef]

66. Mordue, A.J.; Nisbet, A.J. Azadirachtin from the Neem tree Azadirachta indica: Its actions against insects. An. Soc. Entomol. Brasil 2000, 29, 615-632.

67. Hassan, E.; Gökçe, A. Production and consumption of biopesticides. In Advances in Plant Biopesticides, 1st ed.; Springer: New Delhi, India, 2014; pp. 361-379.

68. Roahk, R.C. Present status of rotenone and rotenoids. J. Econ. Entomol. 1941, 34, 684-692. [CrossRef]

69. Zehnder, G.W. Timing of insecticides for control of Colorado potato beetle (Coleoptera: Chrysomelidae) in eastern Virginia based on differential susceptibility of life stages. J. Econ. Entomol. 1986, 79, 851-856. [CrossRef]

70. EC (European Commission). Concerning the Non-Inclusion of Rotenone, Extract from Equisetum and Chinin-Hydrochlorid in Annex I to Council Directive 91/414/EEC and the Withdrawal of Authorisations for Plant Protection Products Containing These Substances. EC 2008/317, Published 10 April 2008. Available online: https://eur-lex.europa.eu/LexUriServ/LexUriServ.do?uri=OJ:L:2008:108:0030:0032:EN:PDF (accessed on 28 October 2020).

71. DG SanCo (European Union Director General for Health and Consumers). Available online: https: //ec.europa.eu/info/departments/health-and-food-safety_en (accessed on 28 October 2020).

72. Kesdek, M.; Kordali, S.; Usanmaz, A.; Ercisli, S. The toxicity of essential oils of some plant species against adults of colorado potato beetle, Leptinotarsa decemlineata Say (Coleoptera: Chrysomelidae). Tome 2015, 68, 127-136.

73. Ebadollahi, A.; Geranmayeh, J.; Kamrani, M. Colorado potato beetle (Leptinotarsa decemlineata Say) control potential of essential oil isolated from iranian Cymbopogon citratus Stapf. Nat. Prod. 2017, 23, 235-238. [CrossRef]

74. Gökçe, A.; Isaacs, R.; Whalon, M.E. Behavioural response of Colorado potato beetle (Leptinotarsa decemlineata) larvae to selected plant extracts. Pest Manag. Sci. 2006, 62, 1052-1057. [CrossRef] [PubMed]

75. Alkan, M.; Gökçe, A.; Kara, K. Contact Toxicity of Six Plant Extracts to Different Larval Stages of Colorado Potato Beetle (Leptinotarsa decemlineata Say (Col: Chrysomelidae)). J. Agric. Sci. 2017, 23, 309-316.

76. Ertürk, Ö.; Sarıkaya, A. Effects of Various Plant Extracts on the Development of the Potato Beetle under Laboratory and Field Conditions: A Combined Study. J. Entomol. Res. Soc. 2017, 19, 101-112.

77. Bădeanu, M.; Şuteu, D.; Chiorescu, E.; Filipov, F. The use of medicinal and aromatic plant extracts against Colorado beetle species-Leptinotarsa decemlineata (Coleoptera-Chrysomelidae). Rev. Bot. 2017, 14, 101-104.

78. Scott, I.M.; Jensen, H.; Scott, J.G.; Isman, M.B.; Arnason, J.T.; Philogene, B.J.R. Botanical insecticides for controlling agricultural pests: Piperamides and the Colorado potato beetle Leptinotarsa decemlineata Say (Coleoptera: Chrysomelidae). Arch. Insect Biochem. 2003, 54, 212-225. [CrossRef]

79. Scott, I.M.; Jensen, H.R.; Philogène, B.J.; Arnason, J.T. A review of Piper spp.(Piperaceae) phytochemistry, insecticidal activity and mode of action. Phytochem. Rev. 2008, 7, 65. [CrossRef]

80. Rusin, M.; Gospodarek, J.; Biniaś, B. The effect of water extract from wild thyme on Colorado potato beetle feeding. Ecol. Eng. 2016, 17, 197-202. [CrossRef]

81. Gabaston, J.; El Khawand, T.; Waffo-Teguo, P.; Decendit, A.; Richard, T.; Mérillon, J.M.; Pavela, R. Stilbenes from grapevine root: A promising natural insecticide against Leptinotarsa decemlineata. J. Pest Sci. 2018, 91, 897-906. [CrossRef]

82. Trdan, S.; Cirar, A.; Bergant, K.; Andjus, L.; Kač, M.; Vidrih, M.; Rozman, L. Effect of temperature on efficacy of three natural substances to Colorado potato beetle, Leptinotarsa decemlineata (Coleoptera: Chrysomelidae). Acta Agric. Scand. B 2007, 57, 293-296. [CrossRef]

83. Bohinc, T.; Vučajnk, F.; Trdan, S. The efficacy of environmentally acceptable products for the control of major potato pests and diseases. Zemdirbyste 2019, 106, 135-142. [CrossRef]

84. Banken, J.A.; Stark, J.D. Multiple routes of pesticide exposure and the risk of pesticides to biological controls: A study of neem and the sevenspotted lady beetle (Coleoptera: Coccinellidae). J. Econ. Entomol. 1998, 91, 1-6. [CrossRef]

85. Murray, K. Utilization of a neem product in a reduced synthetic chemical insecticidal management program for Colorado potato beetle. Sustain. Agric. Netw. 1997, 24, 1275-1283.

86. Bezjak, S.; Igrc Barčić, J.; Bažok, R. Efficacy of botanical insecticides in Colorado potato beetle (Leptinotarsa decemlineata, Say., Coleoptera:Chrysomelidae) control. Fragm. Phytomed. Herbol. 2006, 29, 13-24. 
87. Ebrahimi, L.; Niknam, G.; Lewis, E.E. Lethal and sublethal effects of Iranian isolates of Steinernema feltiae and Heterorhabditis bacteriophora on the Colorado potato beetle, Leptinotarsa decemlineata. BioControl 2011, 56, 781-788. [CrossRef]

88. Toba, H.H.; Lindegren, J.E.; Turner, J.E.; Vail, P.V. Susceptibility of the Colorado potato beetle and the sugarbeet wireworm to Steinernema feltiae and S. glaseri. J. Nematol. 1983, 15, 597.

89. Kepenekci, I. Infectivity of Native Entomopathogenic Nematodes Applied as Infected-Host Cadavers against the Colorado Potato Beetle, Leptinotarsa decemlineata (Say) (Coleoptera: Chrysomelidae). Egypt. J. Biol. Pest Control 2016, 26, 173.

90. Laznik, Ž.; Tóth, T.; Lakatos, T.; Vidrih, M.; Trdan, S. Control of the Colorado potato beetle (Leptinotarsa decemlineata [Say]) on potato under field conditions: A comparison of the efficacy of foliar application of two strains of Steinernema feltiae (Filipjev) and spraying with thiametoxam. J. Plant Dis. Protect 2010, 117, 129-135. [CrossRef]

91. Trdan, S.; Vidrih, M.; Andjus, L.; Laznik, Ž. Activity of four entomopathogenic nematode species against different developmental stages of Colorado potato beetle, Leptinotarsa decemlineata (Coleoptera, Chrysomelidae). Helminthologia 2009, 46, 14-20. [CrossRef]

92. Trdan, R.E.; Liu, J.; Reed, G. Comparison of endemic and exotic entomopathogenic nematode species for control of Colorado potato beetle (Coleoptera: Chrysomelidae). J. Econ. Entomol. 1997, 90, 1528-1533.

93. Ghassemi-Kahrizeh, A.; Aramideh, S. Sub-lethal effects of Bacillus thuringiensis Berliner on larvae of Colorado potato beetle, Leptinotarsa decemlineata (say) (Coleoptera: Chrysomelidae). Arch. Phytopathol. Pflanzenschutz 2015, 48, 259-267. [CrossRef]

94. Wraight, S.P.; Ramos, M.E. Synergistic interaction between Beauveria bassiana-and Bacillus thuringiensis tenebrionis-based biopesticides applied against field populations of Colorado potato beetle larvae. J. Invertebr. Pathol. 2005, 90, 139-150. [CrossRef]

95. Weinzierl, R.; Henn, T.; Koehler, P.G.; Tucker, C.L. Microbial Insecticides, Cooperative Extension Service; University of Illinois: Gainesville, FL, USA, 1998; Volume 1295, pp. 11-23.

96. Barčić, J.I.; Bažok, R.; Bezjak, S.; Čuljak, T.G.; Barčić, J. Combinations of several insecticides used for integrated control of Colorado potato beetle (Leptinotarsa decemlineata, Say., Coleoptera: Chrysomelidae). J. Pest Sci. 2006, 79, 223-232. [CrossRef]

97. Osman, M.A.M. Biological efficacy of some biorational and conventional insecticides in the control of different stages of the Colorado potato beetle, Leptinotarsa decemlineata (Say) (Coleoptera: Chrysomelidae). Plant Protect. Sci. 2010, 46, 123-134. [CrossRef]

98. Bažok, R.; Đurek, I.; Barčić, J.I.; Čuljak, T.G. Joint action of ecologically acceptable insecticides for the Colorado Potato Beetle (Leptinotarsa decemlineata Say, Coleoptera: Chrysomelidae) control. Fragm. Phytomed. Herbol. 2008, 30, 47-63.

99. Kovaříková, K.; Pavela, R. United Forces of Botanical Oils: Efficacy of Neem and Karanja Oil against Colorado Potato Beetle under Laboratory Conditions. Plants 2019, 8, 608. [CrossRef]

100. Trisyono, A.; Whalon, M.E. Toxicity of neem applied alone and in combinations with Bacillus thuringiensis to Colorado potato beetle (Coleoptera: Chrysomelidae). J. Econ. Entomol. 1999, 92, 1281-1288. [CrossRef]

101. Maliszewska, J.; Tegowska, E. Capsaicin as an organophosphate synergist against Colorado potato beetle (Leptinotarsa decemlineata Say). J. Plant Prot. Res. 2012, 52, 28-34. [CrossRef]

102. Heimpel, G.E.; Hough-Goldstein, J.A. A survey of arthropod predators of Leptinotarsa decemlineata (Say) in Delaware potato fields. J. Agric. Entom. 1992, 9, 137-142.

103. Ferro, D.N. Biological control of the Colorado potato beetle. APS 1994, 11, 357-375.

104. Hilbeck, A.; Kennedy, G.G. Predators feeding on the Colorado potato beetle insecticide-free plots and insecticide-treated commercial potato fields in eastern North Carolina. Biol. Control. 1996, 6, $273-282$. [CrossRef]

105. Snyder, W.E. Give predators a complement: Conserving natural enemy biodiversity to improve biocontrol. Biol. Control 2019, 135, 73-82. [CrossRef]

106. Radkova, M.; Kalushkov, P.; Chehlarov, E.; Gueorguiev, B.; Naumova, M.; Ljubomirov, T.; Stoichev, S.; Slavov, S.; Djilianov, D. Beneficial arthropod communities in commercial potato fields. Compt. Rend. Acad. Bulg. Sci. 2017, 70, 309-316. 
107. Tschumi, M.; Albrecht, M.; Collatz, J.; Dubsky, V.; Entling, M.H.; Najar-Rodriguez, A.J.; Jacot, K. Tailored flower strips promote natural enemy biodiversity and pest control in potato crops. J. Appl. Ecol. 2016, 53, 1169-1176. [CrossRef]

108. Crowder, D.W.; Northfield, T.D.; Strand, M.R.; Snyder, W.E. Organic agriculture promotes evenness and natural pest control. Nature 2010, 466, 109-112. [CrossRef]

109. Turnbull, L.A.; Hector, A. How to get even with pests. Nature 2010, 466, 36-37. [CrossRef]

110. Johnson, J.M.; Hough-Goldstein, J.A.; Vangessel, M.J. Effects of straw mulch on pest insects, predators, and weeds in watermelons and potatoes. Environ. Entomol. 2004, 33, 1632-1643. [CrossRef]

111. Dudás, P.; Gedeon, C.; Menyhárt, L.; Ambrus, G.; Tóth, F. The effect of mulching on the abundance and diversity of ground beetle assemblages in two hungarian potato fields. J. Environ. Agric. Sci. 2016, 3, 45-53. [CrossRef]

112. Nelson, K.L.; Lynch, D.H.; Boiteau, G. Assessment of changes in soil health throughout organic potato rotation sequences. Agric. Ecosyst. Environ. 2009, 131, 220-228. [CrossRef]

113. Werling, B.P.; Gratton, C. Influence of field margins and landscape context on ground beetle diversity in Wisconsin (USA) potato fields. Agric. Ecosyst. Environ. 2008, 128, 104-108. [CrossRef]

114. Duan, J.J.; Head, G.; Jensen, A.; Reed, G. Effects of transgenic Bacillus thuringiensis potato and conventional insecticides for Colorado potato beetle (Coleoptera: Chrysomelidae) management on the abundance of ground-dwelling arthropods in Oregon potato ecosystems. Environ. Entomol. 2004, 33, 275-281. [CrossRef]

115. Meissle, M.; Lang, A. Comparing methods to evaluate the effects of $B t$ maize and insecticide on spider assemblages. Agric. Ecosyst. Environ. 2005, 107, 359-370. [CrossRef]

116. Smith, J.; Wolfe, M.; Woodward, L.; Pearce, B.; Lampkin, N.; Marshall, H. Organic Farming and Biodiversity: A Review of the Literature; Organic Center Wales: Aberystwyth, Wales, 2011.

117. Hald, A.B. Weed vegetation (wild flora) of long established organic versus conventional cereal fields in Denmark. Ann. Appl. Biol. 1999, 134, 307-314. [CrossRef]

118. Krauss, J.; Gallenberger, I.; Steffan-Dewenter, I. Decreased functional diversity and biological pest control in conventional compared to organic crop fields. PLoS ONE 2011, 6, e19502. [CrossRef]

119. Fuller, R.J.; Norton, L.R.; Feber, R.E.; Johnson, P.J.; Chamberlain, D.E.; Joys, A.C.; Mathews, F.; Stuart, R.C.; Townsend, M.C.; Manley, W.J.; et al. Benefits of organic farming to biodiversity vary among taxa. Biol. Lett. 2005, 1, 431-434. [CrossRef]

120. Macfadyen, S.; Gibson, R.; Polaszek, A.; Morris, R.J.; Craze, P.G.; Planqué, R.; Symondson, W.O.; Memmott, J. Do differences in food web structure between organic and conventional farms affect the ecosystem service of pest control? Ecol. Lett. 2009, 12, 229-238. [CrossRef]

121. Geiger, F.; Hegemann, A.; Gleichman, M.; Flinks, H.; de Snoo, G.R.; Prinz, S.; Tieleman, B.I.; Berendse, F. Habitat use and diet of Skylarks (Alauda arvensis) wintering in an intensive agricultural landscape of the Netherlands. J. Ornithol. 2014, 155, 507-518. [CrossRef]

122. Sugiyama, A.; Vivanco, J.M.; Jayanty, S.S.; Manter, D.K. Pyrosequencing assessment of soil microbial communities in organic and conventional potato farms. Plant Dis. 2010, 94, 1329-1335. [CrossRef] [PubMed]

123. Rusch, A.; Bommarco, R.; Ekbom, B. Conservation biological control in agricultural landscapes. In Advances in Botanical Research, 1st ed.; Academic Press: Cambridge, MA, USA, 2017; Volume 81, pp. 333-360.

124. Alfoeldi, T.; Fliessbach, A.; Geier, U.; Kilcher, L.; Niggli, U.; Pfiffner, L.; Stolze, M.; Willer, H. Organic agriculture and the environment. In Organic Agriculture, Environment and Food Security; El-Hage Scialabba, N., Hattam, C., Eds.; Environment and Natural Resources Series 4; Food and Agriculture Organisation of the United Nations (FAO): Rome, Italy, 2002.

125. Patt, J.M.; Hamilton, G.C.; Lashomb, J.H. Impact of strip-insectary intercropping with flowers on conservation biological control of the Colorado potato beetle. Adv. Hortic. Sci. 1997, 175-181.

126. Alyokhin, A.; Porter, G.; Groden, E.; Drummond, F. Colorado potato beetle response to soil amendments: A case in support of the mineral balance hypothesis? Agric. Ecosyst. Environ. 2005, 109, 234-244. [CrossRef]

127. Sidauruk, L.; Sipayung, P. Cropping management on potato field, a strategy to suppress pest by increasing insect diversity and natural enemies. In Proceedings of the International Conference on Agribussines, Food and Agro-Technology, Medan, Indonesia, 19-21 September 2018; IOP Publishing: Bristol, UK, 2018; Volume 205, p. 012026.

128. Dvorák, P.; Kuchtová, P.; Tomásek, J. Response of surface mulching of potato (Solanum tuberosum) on SPAD value, Colorado potato beetle and tuber yield. Int. J. Agric. Biol. 2013, 15, 798-800. 
129. Brust, G.E. Natural enemies in straw-mulch reduce Colorado potato beetle populations and damage in potato. Biol. Control 1994, 4, 163-169. [CrossRef]

130. Suja, G.; Sundaresan, S.; John, K.S.; Sreekumar, J.; Misra, R.S. Higher yield, profit and soil quality from organic farming of elephant foot yam. Agron 2012, 32, 755-764. [CrossRef]

131. Murphy, K.M.; Campbell, K.G.; Lyon, S.R.; Jones, S.S. Evidence of varietal adaptation to organic farming systems. Field Crops Res. 2007, 102, 172-177. [CrossRef]

132. Alyokhin, A.; Mota-Sanchez, D.; Baker, M.; Snyder, W.E.; Menasha, S.; Whalon, M.; Dively, G.; Moarsi, W.F. The Red Queen in a potato field: Integrated pest management versus chemical dependency in Colorado potato beetle control. Pest Manag. Sci. 2015, 71, 343-356. [CrossRef]

133. Azfar, S.; Nadeem, A.; Basit, A. Pest detection and control techniques using wireless sensor network: A review. J. Entomol. 2015, 3, 92-99.

134. Shennan, C. Biotic interactions, ecological knowledge and agriculture. Philos. Trans. R. Soc. B 2008, 363, 717-739. [CrossRef]

Publisher's Note: MDPI stays neutral with regard to jurisdictional claims in published maps and institutional affiliations.

(C) 2020 by the authors. Licensee MDPI, Basel, Switzerland. This article is an open access article distributed under the terms and conditions of the Creative Commons Attribution (CC BY) license (http://creativecommons.org/licenses/by/4.0/). 